\title{
Biochemistry and physiology of zebrafish photoreceptors
}

\author{
Jingjing Zang ${ }^{1} \cdot$ Stephan C. F. Neuhauss ${ }^{1}$ (D)
}

Received: 3 December 2020 / Revised: 25 January 2021 / Accepted: 28 January 2021 / Published online: 17 February 2021

(C) The Author(s) 2021

\begin{abstract}
All vertebrates share a canonical retina with light-sensitive photoreceptors in the outer retina. These photoreceptors are of two kinds: rods and cones, adapted to low and bright light conditions, respectively. They both show a peculiar morphology, with long outer segments, comprised of ordered stacks of disc-shaped membranes. These discs host numerous proteins, many of which contribute to the visual transduction cascade. This pathway converts the light stimulus into a biological signal, ultimately modulating synaptic transmission. Recently, the zebrafish (Danio rerio) has gained popularity for studying the function of vertebrate photoreceptors. In this review, we introduce this model system and its contribution to our understanding of photoreception with a focus on the cone visual transduction cascade.
\end{abstract}

Keywords Zebrafish $\cdot$ Visual transduction $\cdot$ Photoreceptors $\cdot$ Cones

\section{Introduction}

All vertebrates share a canonical retina with light-sensitive photoreceptors in the outer retina. These photoreceptors are of two kinds: rods and cones. Rod photoreceptors are characterized by higher light sensitivity and slower kinetics, mainly mediating monochromatic low-light vision [191, 50, 57, 105]. Cone photoreceptors on the other hand function under bright light, conveying luminance and color information. In vertebrates, they come in up to four different subtypes, depending on their peak absorption. Both photoreceptor types share a peculiar morphology with a large outer segment comprised of an ordered stack of discs, which contain the proteins of the visual transduction cascade. This biochemical pathway transforms the physical stimulus of light into a biological signal. Outer segments are modified primary cilia that are connected via an axoneme to the mitochondrium-rich inner segment [84]. Synapses of the photoreceptors are among the most complex synapses in the vertebrate brain, featuring ribbons

This article is part of the special issue on Function and Dysfunction in Vertebrate Photoreceptor Cells in Pflügers Archiv—European Journal of Physiology

Stephan C. F. Neuhauss

stephan.neuhauss@mls.uzh.ch

1 Department of Molecular Life Sciences, University of Zurich, Winterthurerstrase 190, CH - 8057 Zürich, Switzerland that are thought to enable tonic glutamate release into the synapse $[162,175]$.

Photoreceptors have been intensively studied in different model organisms. Biochemists favor large bovine eyes for their large yield of proteins. Electrophysiologists favor the amphibians for their comparatively large photoreceptors and geneticists have mainly focused on rodent eyes due to the genetic amenities available in these systems.

More recently, the small tropical teleost zebrafish (Danio rerio) joined the ranks of model system for retinal research. Besides their favorable biological properties, such as small body size, easy maintenance, and large number of offspring, there are several properties of their visual system that have endeared this model system to visual scientists [157]. Unlike the rod-dominant amphibian or rodent retina, the majority of photoreceptors in zebrafish are cones, with about $92 \%$ in zebrafish larvae and about $60 \%$ in the adult $[49,2,222]$. The larval retina also serves as a model for the primate fovea, featuring a cone-rich acute zone responsible for prey detection [212]. Moreover, more than $70 \%$ of human genes have direct orthologues in the zebrafish genome [69], making zebrafish an ideal model to study eye or more specifically cone diseases in humans $[61,11,113]$. The genetic toolbox to manipulate zebrafish has massively expanded during the past decade, including DNA insertion, precisely controlled transgene expression, and CRISPR/Cas genome editing [131]. Because the zebrafish retina starts to transmit visual information at very early stages ( 3 days post fertilization (dpf)), the function of the visual system can be assessed at early larval stages. 
Finally, zebrafish larvae are transparent, making them well suited for live imaging (e.g., [135, 222]).

Zebrafish retina signaling with related ocular and retinal diseases have been reviewed recently $[8,123,113,126,18$, 11]. In this review, we will provide an overview of biochemical and physiological processes in zebrafish photoreceptors with a focus on the visual transduction cascade, the very first step of image-forming vision.

\section{Zebrafish outer retina}

The zebrafish retina possesses one rod type and four morphologically and spectrally distinct cone subtypes, namely short single cones (ultraviolet (UV)-sensitive), long single cones (blue-sensitive), double cone accessory members (green-sensitive), and double-cone principle members (red-sensitive). Double cones exist in most vertebrates, but are absent in most placental mammals, elasmobranches, and catfish [44]. Zebrafish photoreceptors are coupled by gap junction, mainly mediated by Connexin 35 (the zebrafish homologue of mammalian Cx36) [111]. Fish photoreceptor coupling is regulated by the circadian clock, with cone-cone and rod-cone coupling being increased during nighttime [151, 111].

In the absence of pupillary reflexes, many lower vertebrates developed retinomotor movements to adapt to changes in light conditions. In darkness, a mobile part of photoreceptor inner segment, called the myoid, drives cones to elongate and rods to contract [124, 67]. Meanwhile, pigment granules (melanosomes) of the retinal pigment epithelium (RPE) concentrate at the basal part of the RPE. In this way, cone outer segments are buried deeply inside basal RPE while rod outer segments are optimally exposed to incoming light, by being situated far from pigment granules. During light adaptation, cones contract while rods elongate concomitant to pigment granule translocation towards the apical part of the RPE. Therefore, cone outer segments are exposed to light and the rod outer segments are protected by the RPE, akin to sunglasses [1]. The zebrafish retina shows adult-like retinomotor movement from $28 \mathrm{dpf}$ on. Pigment granules take about an hour to migrate to fully light adapted position, while double cone outer segment contraction finishes in about 20 minutes $[124,67]$

Longitudinal sections of adult retina demonstrate that different photoreceptors are organized into different layers in zebrafish $[153,20]$ (Fig. 1a, b). The nuclei of rods are located distal to all cone nuclei. The nuclei of UV cones, blue cones, and double cones are located in the distal, medial, and proximal zones of the outer retina, respectively. Cone photoreceptors in the adult zebrafish retina are orderly arranged into a row mosaic pattern (Fig. 1c), in which a red cone neighbors a blue cone while a green cone neighbors a UV cone [2,107].
Rods project into a square shape around each UV cone to form an integral photoreceptor mosaic [49].

The situation is different in the larval retina, where photoreceptors are anisotropically distributed [222]. All cone types are concentrated at the horizon and lower visual field, which may mediate color vision. UV cone density shows a peak at around $30^{\circ}$ above the horizon, which is essential for visual prey hunting [212]. The upper visual field is dominated by rods, supporting the effectively achromatic vision towards the sky. This anisotropic distribution is adapted to the spectral content in the natural visual environment serving behavioral demands.

\section{Visual transduction cascade}

The main function of photoreceptors is the capture of photons of visual light and the subsequent transformation of this physical stimulus into a biological signal, ultimately modifying the release of the neurotransmitter glutamate by the photoreceptor synapse $[50,105,57,22]$. The visual transduction cascade and its regulation are among the best-understood trimeric G protein signaling pathways. All reactions take place in the outer segments of photoreceptors, most of them associated with the membrane (Fig. 2). Zebrafish genes involved in visual transduction cascade are summarized in Table 1.

The photoreceptor outer segment is a cylindrical structure comprised of an ordered stack of disc-shaped membranes, allowing a high concentration of transmembrane visual pigments and increasing the probability of photon catch [92].

Rod and cone photoreceptors share a generally similar visual transduction cascade, but adopt rod- or cone-specific protein isoforms for many of the cascade's components. The evolution of these photoreceptor-specific paralogues is a wellstudied paradigm for the fate of duplicated genes in evolution [103]. This is particularly true for teleost genomes that underwent a lineage-specific whole-genome duplication, following two rounds of whole-genome duplications in the early vertebrate lineage [7, 190, 184].

The generation, deletion, and fate of these duplicated genes add a fascinating complexity to the teleost visual transduction cascade that is beyond the scope of this review. However, the multitude of gene variants to be discussed in the following is the direct consequence of whole-genome duplications in the past $[63,103,104,106,99,100,60]$.

The visual transduction cascade is initiated by the absorption of photons by opsins. These G protein-coupled 7transmembrane receptors are covalently bound to a lightsensitive chromophore via a Schiff base forming the photopigment complex [73]. Upon the absorption of a photon, chromophore (most commonly vitamin $\mathrm{A}_{1}$ 11-cis-retinal) in the photopigment complex isomerizes to all-trans-retinal, which activates the opsin (now referred to $\mathrm{R}^{*}$ ) by inducing a 
a

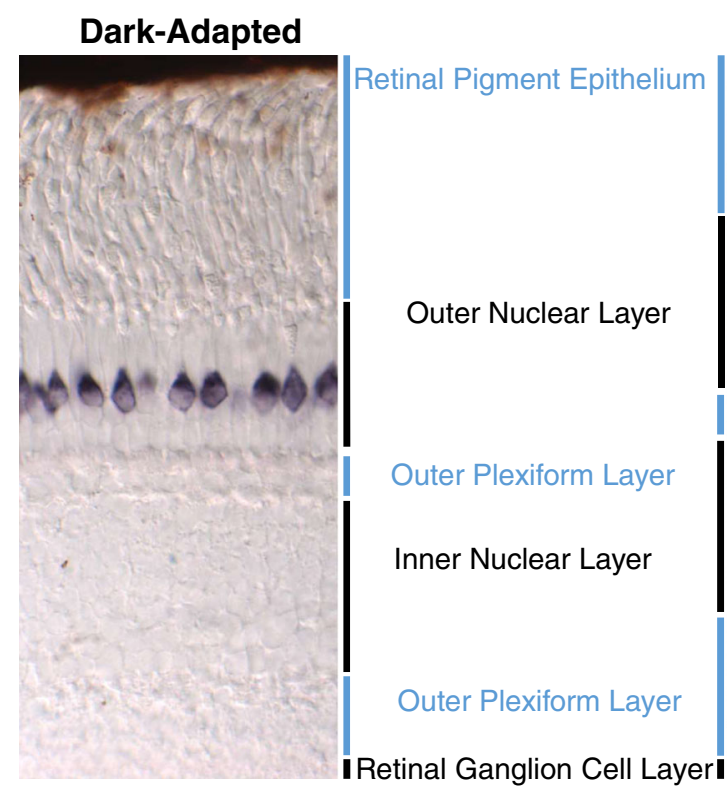

Fig. 1 Adult zebrafish retina and photoreceptor mosaic. Dark-adapted adult zebrafish retina section (a) and light-adapted section (b) are organized into different cellular layers. The nuclei of rod and cone photoreceptors are located in the outer nuclear layer. During light adaptation, photoreceptor myoid drives cones to contract and rods to elongate to b

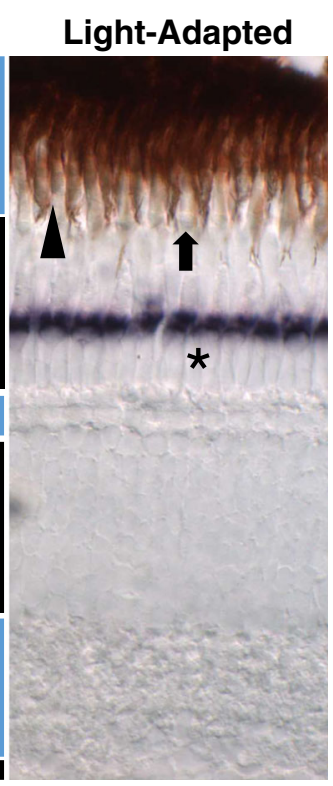

C
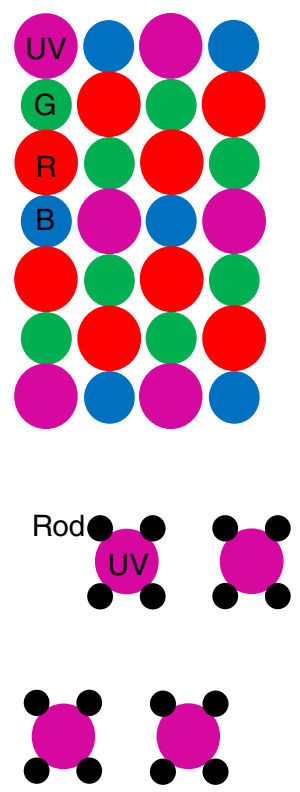

protect rods from over-bleaching, known as retinomotor movement. UV opsin $(s w s 1)$ is labeled by in situ hybridization. Arrowhead denotes double cone. Arrow denotes blue cone. Star denotes cell body of rod. Schematic of the zebrafish photoreceptor planar mosaic arrangement (c) $[153,2,49]$. UV, UV cone; R, red cone; G, green cone; B, blue cone

a

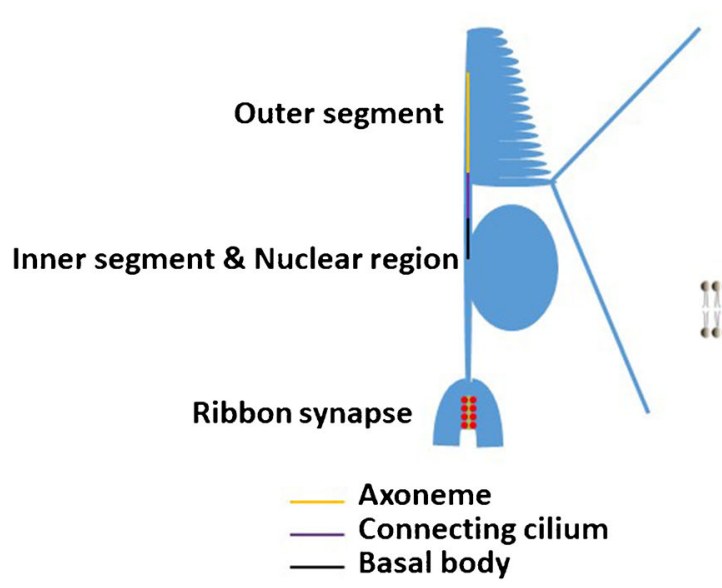

Fig. 2 Cone photoreceptor morphology (a). Schematic representation of vertebrate visual transduction cascade and $\mathrm{Ca}^{2+}$-regulated deactivation processes (b). Photon absorption activates R. R* then triggers the exchange of GTP for GDP on the T $\alpha$. T $\alpha$-GTP binds to cyclic nucleotide PDE. Stimulated PDE hydrolyzes free cyclic guanosine monophosphate (cGMP). In darkness, CNGC allows an influx of $\mathrm{Na}^{+}$and $\mathrm{Ca}^{2+}$, while during illumination CNGC is shut off by cGMP decrease. NCKX is not affected by light, which results in a light-induced intracellular $\mathrm{Ca}^{2+}$ concentration decline. Rcv modulates phosphorylation of $\mathrm{R}^{*}$ via GRK in a $\mathrm{Ca}^{2+}$-dependent manner. Phosphorylated $\mathrm{R}$ then is fully deactivated by

b
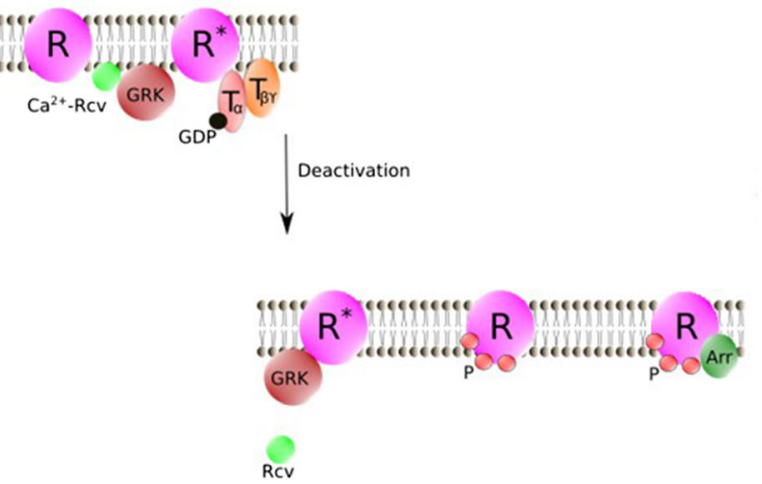

the binding of Arr. R, visual pigment (inactive); $\mathrm{R}^{*}$, light-activated visual pigment; T $\alpha$, transducin $\alpha$ subunit; T $\beta \gamma$, transducin $\beta$ and $\gamma$ subunits; PDE, phosphodiesterase (inactive); PDE*, PDE-transducin $\alpha$ complex: NCKX, $\mathrm{Na}^{+} / \mathrm{Ca}^{2+}, \mathrm{K}^{+}$exchanger; Arr, arrestin; GRK, G protein-coupled receptor kinase; Rcv, Recoverin; CNGC, cyclic nucleotide-gated ion channel; P, phosphorylation; M, CNG-modulin; GC, guanylate cyclase; GCAP, guanylate cyclase activating protein. Figure was drawn using Inkscape. Inkscape http://www.inkscape.org/. Reproduced with permission from Zang and Neuhauss [217] 


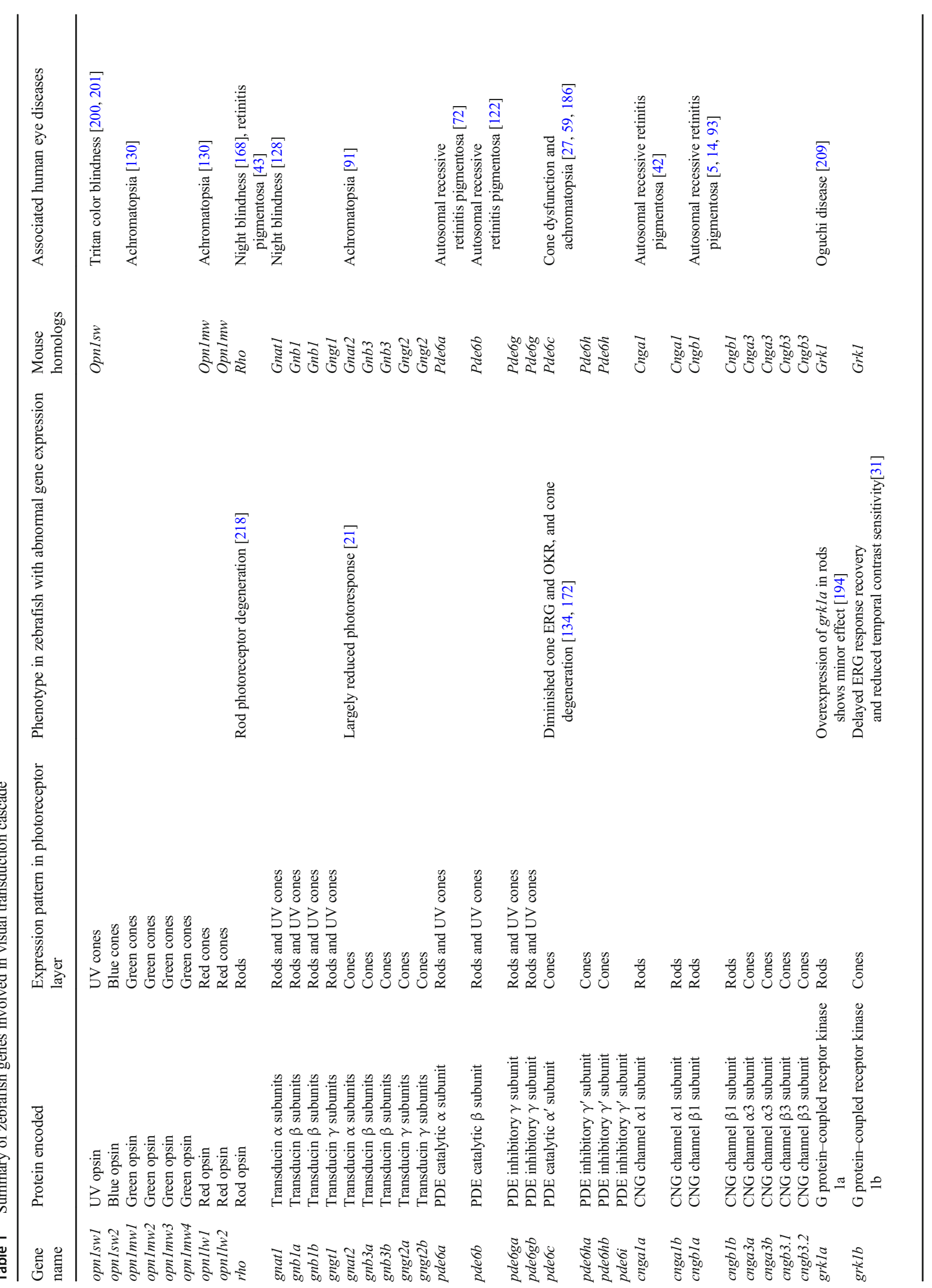




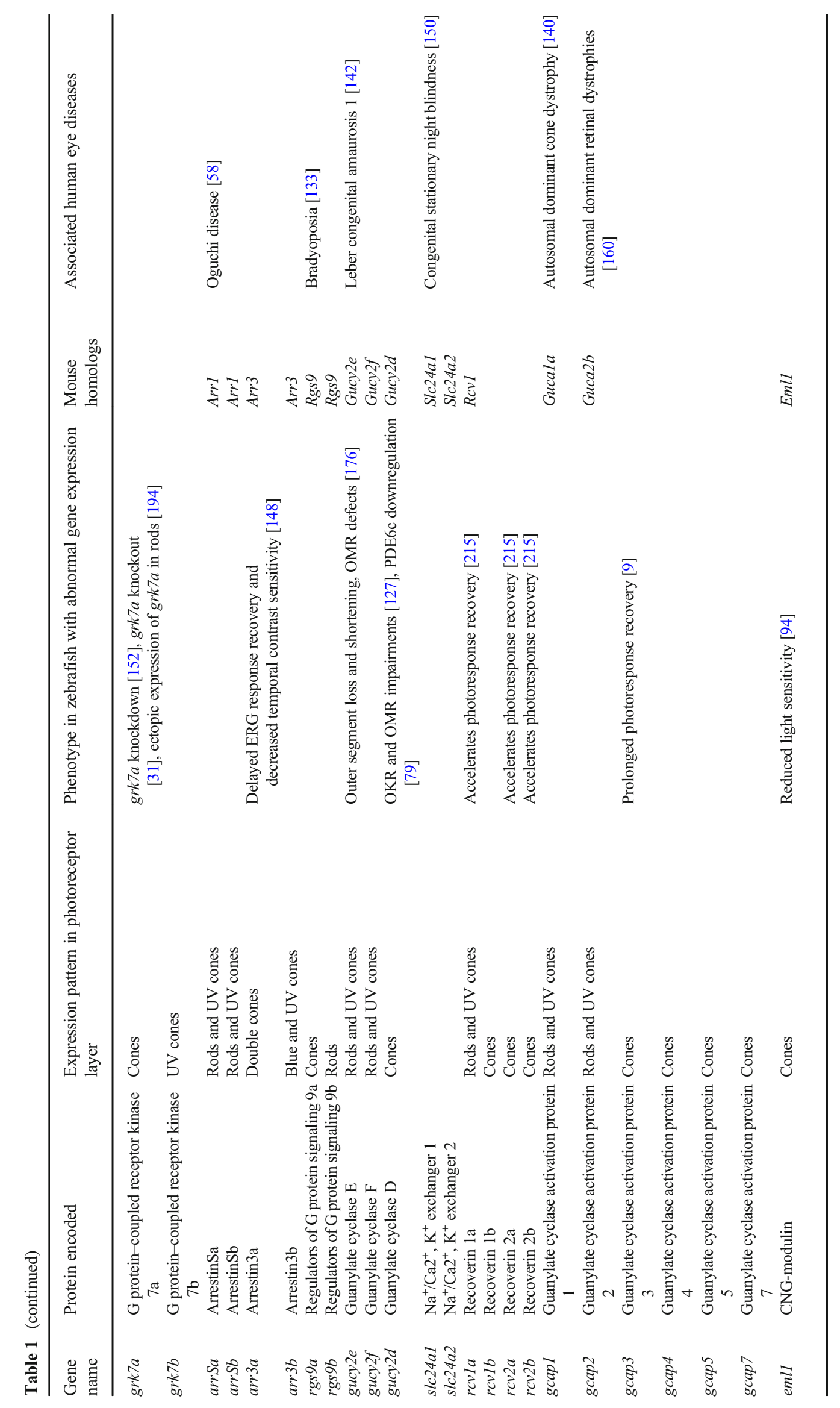


transformational change [51, 52]. Zebrafish cones express a total of 8 cone opsins, namely opn 1 sw 1 (also known as $\operatorname{sws} 1$ ), opn1sw2 (also known as sws2), opn1mw1 (also known as rh21), opn1mw2 (also known as rh2-2), opn1mw3 (also known as rh2-3), opn1mw4 (also known as rh2-4), opn1lw1 (also known as $l w s 1$ ), and opn $1 l w 2$ (also known as $l w s 2$ ) [2, 145, 182]. Hence, there are four green (short wave length) and two red (long wavelength) opsin variants. These variants have slightly different peak absorption properties potentially allowing a bewildering range of fine-tuning of color perception $[30,23]$. The expressions of these multiple $r h 2$ and $l w s$ genes follow a spatiotemporal order during development [182]. Rod photoreceptors express only a single-rod opsin gene rho (also known as rhl) [218]. Mutations in human rod opsin may produce night blindness or retinal degeneration, while cone opsin defects may lead to achromatopsia [168, 43, $130,200,201]$. For years, vitamin $\mathrm{A}_{1}$-based photopigment has been recognized as the sole photopigment existing in zebrafish photoreceptors under standard laboratory conditions $[23,30]$. The peak absorption spectra $\left(\lambda_{\max }\right)$ of $A_{1}$-based photopigments differ markedly and cover a wide spectrum from $355 \mathrm{~nm}$ (UV) to $558 \mathrm{~nm}$ (red) in vivo. However, thyroid hormone $(\mathrm{TH})$ treatment or colder water temperature may result in a transition from $\mathrm{A}_{1}$ to vitamin $\mathrm{A}_{2}$ (11-cis 3,4didehydroretinal)-based photopigments. This demonstrates a functional $\mathrm{A}_{1}-\mathrm{A}_{2}$ photopigment interchange system in zebrafish [159, 3, 48]. The $\lambda_{\max }$ of $\mathrm{A}_{2}$-based photopigments shifts towards longer wavelength relative to $A_{1}$-based photopigment $[115,66]$. This interchange system is frequently observed in freshwater fishes and amphibians, and may be adapted to the red-shifted light environment in fresh water compared with marine and terrestrial environments [149, 197, 222]. Another mechanism to tune photopigments is to change opsin expression levels. TH treatment has been reported to reduce $l w s 2(548 \mathrm{~nm})$ and $r h 2-1(467 \mathrm{~nm})$, while increasing $l w s 1(558 \mathrm{~nm})$ and $r h 2-2(488 \mathrm{~nm})$ in larvae, favoring the opsins with longer $\lambda_{\max }$ [119]. Both the mechanisms red-shift the zebrafish photoreceptor spectral sensitivity. Moreover, in TH receptor-defective fish, retinal progenitors designed to become red cones are transfated into UV cones, providing another mechanism for TH to regulate long-wavelength vision [180, 195, 37].

Besides the visual opsins, the zebrafish genome harbors 32 nonvisual opsin genes, which encode opsins forming functional photopigments with different chromophores [35, 34 , 56]. Many, but not all of them, are expressed in the photoreceptor layer. Their functions in photoreceptors are largely unknown, but a role in circadian light entrainment is discussed $[56,174,26]$.

Activated opsin $\left(\mathrm{R}^{*}\right)$ interacts with the trimeric $\mathrm{G}$ protein transducin $[22,50,105]$. Binding of $\mathrm{R}^{*}$ to transducin results in the replacement of GDP by GTP at the active site of the transducin $\alpha$ subunit. This nucleotide exchange dissociates the activated $\alpha$ subunit $\left(\mathrm{G} \alpha^{*}\right)$ and the heterodimer of $\beta$ and $\gamma$ subunits $(\mathrm{G} \beta \gamma)$. G $\alpha *$ then binds to the cGMP Phosphodiesterase 6 (PDE6) [91, 128].

Zebrafish rod and cone photoreceptors express different variants of three subunits $[99,28]$. In rods, gnat 1 encodes transducin $\alpha$ subunits, gnbla and gnblb encode $\beta$ subunits, and gngt 1 encodes $\gamma$ subunits (all these variants possibly also in UV cones), while in cones, gnat 2 encodes $\alpha$ subunits, gnb $3 a$ and gnb $3 b$ encode $\beta$ subunits, and gngt $2 a$ and gngt $2 b$ encode $\gamma$ subunits.

Surprisingly, a zebrafish mutant defective in the conespecific gnat 2 gene (no optokinetic response $f($ nof)) shows a residual photoresponse that needs to be mediated by an unknown transducin-independent mechanism [21].

Interestingly, both $\mathrm{G} \alpha$ and $\mathrm{G} \beta$ show massive light-induced translocation from rod outer segment to inner segment in mice, which may contribute to light adaptation in rods [170]. However, $\mathrm{G} \alpha$ translocation has not been observed in zebrafish cones (or mouse cone), indicating light adaptation mechanisms may vary between rods and cones [85, 46, 114].

When $\mathrm{G} \alpha *$ binds to PDE6, two PDE6 inhibitory subunits dissociate from the active sites and allow the activation of PDE6 to hydrolyze cGMP [32]. The rod PDE6 variant is expressed as a heterotetramer consisting of two catalytic $\alpha$ and $\beta$ subunits encoded by $p d e 6 a$ and $p d e 6 b$, and two identical inhibitory $\gamma$ subunits encoded by $p d e 6 g$. Cone PDE6 comprises two homodimers of two catalytic $\alpha^{\prime}$ subunits encoded by pde6c and two inhibitory $\gamma^{\prime}$ subunits encoded by pde6h [106, 62, 32, 72, 122].

Zebrafish retain the same set of catalytic subunit genes as in humans ( $p d e 6 a, p d e 6 b$, and $p d e 6 c$ ), while inhibitory subunits are encoded by duplicated paralogues: $p d e 6 g a$ and $p d e 6 g b$ in rods and possibly UV cones and pde6ha and pde6hb in all cones $[100,134]$. An additional inhibitory subunit gene $p d e 6 i$ has also been found in zebrafish, and some other lower vertebrates including fish (teleost and non-teleost) and amphibians [100].

Mutations in the cone-specific $p d e 6 c$ gene are associated with cone dysfunction in human patients with achromatopsia $[27,59,186]$. Mutations in cone-catalytic subunit $p d e 6 c$ result in almost diminished cone electroretinogram (ERG) and optokinetic response (OKR), and cone photoreceptor degeneration in zebrafish $[134,172]$. The mechanism underlying cone degeneration is unknown and is not linked to increased cytosolic $\mathrm{Ca}^{2+}$ levels [118].

Ultimately, the visual transduction cascade regulates the opening of cyclic nucleotide-gated $(\mathrm{CNG})$ ion channels. These non-selective cation channels are opened by cGMP binding [210]. Falling cGMP concentration due to cGMP hydrolysis by PDE6 leads to the closure of these CNG channels, suppressing the circulating dark current and resulting in photoreceptor hyperpolarization. CNG channels are heteromeric proteins consisting of $\alpha$ and $\beta$ subunits [81, 125]. Rod 
channels are assembled from 3 CNGA1 subunits and 1 CNGB1, while cone channels are assembled from 2 CNGA3 subunits and 2 CNGB3 subunits [202, 220, 221, 102].

Mutations in CNGA1 and CNGB1 have been identified in human patients with autosomal-recessive retinitis pigmentosa $[14,5,93,42]$. In zebrafish, all visual CNG channel genes have retained two paralogues, but no additional information is available.

\section{Regulation of visual transduction}

At the biochemical level, visual transduction is mainly regulated by its deactivation kinetics. To deactivate the visual transduction cascade, deactivation of both $\mathrm{R}^{*}$ and $\mathrm{G} \alpha-\mathrm{PDE}^{*}$ complex and the restoration of cGMP concentrations are required $[22,50]$.

The lifetime of $\mathrm{R}^{*}$ is tightly regulated by arrestin proteins that efficiently inactivate photopigmet by binding to its phosphorylated form. Therefore, the first step of $\mathrm{R}^{*}$ inactivation is phosphorylation. $\mathrm{R}^{*}$ is phosphorylated by $\mathrm{G}$ protein-coupled receptor kinases (GRKs). Mice and rats express only GRK1 in both rods and cones, while humans express GRK1 in rods and GRK1 and GRK7 in cones [219, 117, 165, 199]. In zebrafish, both visual $g r k$ genes are present as two paralogues. grkla is expressed exclusively in rods, grklb and grk7a in all cones, and grk7b only in UV cones $[152,196]$ (unpublished data). GRK deficiency in humans leads to Oguchi disease, which is characterized by a delay of rod recovery [209]. A grk7a knockdown model produces largely delayed ERG response recovery and reduced temporal contrast sensitivity in the OKR [152]. Another study demonstrates similar but more modest effects in either grklb or grk7a mutants [31].

Overexpression of grkla in zebrafish rods shows minor effect on rod photoresponse, suggesting that endogenous GRK1a protein is already at saturation levels. Ectopic expression of cone grk $7 a$ in rods resulted in cone-like rod responses [194].

The binding of arrestin completely deactivates the phosphorylated photopigment $[98,203]$. In the mouse retina, both rod (ARR1) and cone (ARR3) arrestins are co-expressed in cone photoreceptors $[132,203]$. Mutations in ARR1 are a cause of Oguchi disease in human [58]. In zebrafish, arrsa and arrsb (orthologues of Arrl) are expressed in rods while arr $3 a$ exists in double cones and arr $3 b$ exists in blue and UV cones, indicating subfunctionalization of the two paralogues. arr $3 a$ knockdown resulted in a severe delay in ERG response recovery and decreased temporal contrast sensitivity [148].

Regulators of $\mathrm{G}$ protein signaling 9 (RGS9) act as GTPase activating protein to deactivate G $\alpha$ *-PDE complex [17]. Mammals have a single $\operatorname{Rgs} 9$ gene, while zebrafish have two $\operatorname{rgs} 9$ genes, with $\operatorname{rgs} 9 a$ being expressed in cones and rgs $9 b$ in rods $[33,104]$ (unpublished data). Inactivating mutations in humans lead to bradyopsia, a rare condition characterized by slower photoreceptor deactivation [133]. A landmark study using Rgs9 overexpression in mice demonstrated its crucial role to rate-limit rod visual transduction recovery [96].

To restore the dark current, cGMP needs to be resynthesized by membrane-bound guanylate cyclases (GCs) $[88,167]$. Photoreceptor-specific GCs are regulated by the small $\mathrm{Ca}^{2+}$-binding guanylate cyclase activation proteins (CGAPs) [90].

Mammals have two photoreceptor-specific GCs, GC-E (known as GC1) and GC-F (known as GC2), both of which are co-expressed in rods and cones $[103,88,60]$. GC-E is more concentrated in cones, while the expression of GC-F is more prominent in rods. Mutations in GC-E have been shown to cause Leber congenital amaurosis 1 (LCA1), a severe form of pediatric blindness in humans [142]. The zebrafish possess 3 GCs. GC-E (known as GC1), GC-F (known as GC2), and GC-D (known as GC3) are encoded by gucy2e (previous name gucy2f), gucy2f (previous name gc2), and gucy2d (previous name $g c 3$ ), respectively. Both gucy2e and gucy $2 f$ are expressed in rods and UV cones, while gucy $2 d$ encodes the only cone-specific GC in all cone subtypes [55, 144].

A zebrafish gucy $2 d$ mutant has been identified in behavioral screen by displaying OKR and optomotor response (OMR) impairments [127]. PDE6c protein levels are downregulated in gucy $2 d$ knockdown larvae, indicating the interdependence between these two regulators of cGMP metabolism [79]. A knockdown of the gucy2d gene results in the loss and shortening of outer segments and defects in the OMR [176].

In darkness, the open non-selective $\mathrm{CNG}$ channels mediate a $\mathrm{Ca}^{2+}$ influx into the photoreceptor outer segment. $\mathrm{Ca}^{2+}$ efflux via $\mathrm{Na}^{+} / \mathrm{Ca}^{2+}, \mathrm{K}^{+}$exchanger (NCKX) balances this influx, producing a moderately high intracellular $\mathrm{Ca}^{2+}$ concentration as shown in rods of different species [101, 207]. Under light illumination, CNG channels are closed due to the decrease in cGMP concentration, while $\mathrm{Ca}^{2+}$ efflux continues, resulting in a decrease of intracellular $\mathrm{Ca}^{2+}$ concentration in the outer segment [211]. This light-induced $\mathrm{Ca}^{2+}$ decline can be simultaneously measured with light response in zebrafish UV cones, demonstrating similar kinetics of $\mathrm{Ca}^{2+}$ extrusion via NCKX to that of CNG channel current [109].

NCKX proteins are encoded by $S L C 24$ gene family members. They show a cell-type-specific expression with NCKX1 being expressed in rods and NCKX2 in cones [193, 147, 143, 150]. NCKX2-deficient mice show no or only mild functional defect, suggesting that compensating transporters may mediate ion exchange as well $[112,156]$. A recent study proposed that NCKX2 and NCKX4 cooperated to facilitate the rapid and efficient extrusion of $\mathrm{Ca}^{2+}$ from mouse cones. NCKX4 has its well-established function in olfactory sensory neurons and is similarly expressed in all cones in the zebrafish retina [192]. The expression pattern of the other NCKX coding 
genes is unknown in zebrafish, but studies in the striped bass show expression of $n c k x l$ in rods and four splice variants of $n c k x 2$ in cones [137].

The reduction of cytoplasmic $\mathrm{Ca}^{2+}$ negatively feedbacks to the phototransduction cascade, triggering the rapid photoresponse recovery and facilitating photoreceptor adaptation to background light $[120,129]$. During light adaptation, photoreceptor light sensitivity is reduced and response kinetics is accelerated, to avoid saturation and to operate across a wide range of environmental light intensity [50]. This has been achieved by mechanisms that primarily involve the regulation of GRKs by Recoverin, GCs by GCAPs, and CNG channels by CNG-modulin (or Calmodulin) $[138,191]$.

Recoverin (RCV) is a small neuronal calcium sensor (NCS), which is primarily located in vertebrate photoreceptors. Upon $\mathrm{Ca}^{2+}$ binding, $\mathrm{RCV}$ undergoes a pronounced conformational change, the so-called $\mathrm{Ca}^{2+}$-myristoyl switch, which translocates the proteins from a cytosolic form to a membrane tethered conformation, allowing targeting and inhibiting GRK proteins [82, 166, 183, 6, 40, 83, 217]. Light stimulation reduces intracellular $\mathrm{Ca}^{2+}$ concentration, allowing the $\mathrm{Ca}^{2+}$-free RCV releasing GRK. GRK disinhibition accelerates $\mathrm{R}^{*}$ phosphorylation, enabling arrestin binding.

While there is only one RCV isoform in mammals (RCV1), four $r c v$ genes are encoded in the zebrafish genome ( $r c v 1 a, r c v 1 b, r c v 2 a$, and $r c v 2 b)$ [215]. $r c v 1 b, r c v 2 a$, and $r c v 2 b$ are cone RCV, while $r c v 1 a$ is expressed in rods and UV cones. Mouse RCV1 experiences a remarkable light-induced translocation from outer and inner segment towards synaptic terminals in rods, which has not been observed in zebrafish photoreceptors by studying all zebrafish RCVs [177] (unpublished observation). Downregulation of cone RCV accelerates photoresponse recovery, but this effect is abolished when cone GRK7a is simultaneously knocked-down. This result not only indicates that RCV regulates opsin deactivation via GRK, but also demonstrates that the cone opsin deactivation kinetics dominates the overall photoresponse shut off kinetics in vivo [215]. Interestingly, different RCVs contribute at distinct light intensities. This implies different $\mathrm{Ca}^{2+}$ sensitivities for these RCVs, since intracellular $\mathrm{Ca}^{2+}$ concentration correlates with light levels [158]. Indeed, a recent biochemical work demonstrated distinct $\mathrm{Ca}^{2+}$ affinities, $\mathrm{Ca}^{2+}$-dependent membrane binding, and $\mathrm{Ca}^{2+}$-induced conformational changes among zebrafish isoforms [45]. Furthermore, salamander cone photoresponse, but not rod response, is also dominated by a $\mathrm{Ca}^{2+}$-sensitive mechanism $[121,216]$. If the $\mathrm{Ca}^{2+}$-sensitive dominance is a general feature in cone photoresponse, it may contribute to the more powerful light adaptation of cones compared to rods.

To restore the dark current, cGMP needs to be resynthesized by GC, which is under the regulation of small
$\mathrm{Ca}^{2+}$-binding proteins called GCAPs [90, 39]. GCAPs belong to the superfamily of EF-hand $\mathrm{Ca}^{2+}$-binding proteins, harboring four EF-hand $\mathrm{Ca}^{2+}$-binding motifs, three of which are functional [89]. Unlike RCVs, GCAPs do not undergo a classical $\mathrm{Ca}^{2+}$-myristoyl switch, but the myristoyl group does play an important role to regulate GCAP properties, including $\mathrm{Ca}^{2+}$ sensitivity, GC affinity, and the catalytic efficiency of the enzyme. $\mathrm{Ca}^{2+}$-binding GCAPs together with GCs form GC/ GCAP complex in darkness. $\mathrm{Ca}^{2+}$ reduction during light exposure triggers a conformational change in GCAPs, which results in a transformational change within the GC/GCAP complex, increases GC catalytic activity and reopens the $\mathrm{CNG}$ channels. During light adaptation, the $\mathrm{Ca}^{2+}$-sensitive GCAP activity will also prevent the closure of all CNG channels and keep photoreceptors responsive.

GCAP1 and 2 are expressed in mammalian rods and cones. The human (but not the mouse) genome also processes a conespecific CGAP3 [75, 140, 160]. Zebrafish photoreceptors express six GCAPs, of which gcap 3, 4, 5, and 7 are restricted to cones and gcapl and 2 are exclusively expressed in rods and $\mathrm{UV}$ cones [76, 144, 54]. These isoforms show distinct $\mathrm{Ca}^{2+}$ sensitivities of $\mathrm{GC}$ activation, $\mathrm{Ca}^{2+} / \mathrm{Mg}^{2+}$-dependent conformational changes, and $\mathrm{Ca}^{2+}$-binding affinities $[164,179]$. Light exposure allows intracellular $\mathrm{Ca}^{2+}$ fluctuating to different levels, in which distinct CGAPs may reach their optimal working range.

GCAP3 is first expressed in a non-myristoylated form in larvae and then becomes myristoylated in the adult retina [54]. Although GCAP3 has been shown to produce the highest $\mathrm{Ca}^{2+}$-dependent activation of GCs in native zebrafish retina, gcap 3 knockdown does not induce any visual behavioral abnormalities [55]. In another study, GCAP3 in green cone was inactivated by antibody injections. Whole-cell patch clamp recordings demonstrated that the photoresponse recovery is strongly prolonged, confirming GCAP3 function to activate GC to restore CNG channel current in cones [9].

cGMP affinity of $\mathrm{CNG}$ channels is regulated in a $\mathrm{Ca}^{2+}-$ dependent manner in all sensory neurons [19]. $\mathrm{Ca}^{2+}$ cannot directly bind to the channels but work via modulator proteins, which have been identified as calmodulin in mammalian rods and CNG-modulin in fish cones [70, 146]. However, the contribution of $\mathrm{CNG}$ channel modulation by $\mathrm{Ca}^{2+}$ in regulating light adaptation is very limited in rods $[29,95]$. On the other hand, CNG-modulin has been shown to regulate the cGMP dependence of $\mathrm{CNG}$ channels in a $\mathrm{Ca}^{2+}$-sensitive manner, and to modulate the light response kinetics in striped bass cone [146]. CNG-modulin is encoded by the emll gene in zebrafish. emll knockdown reduces the light sensitivity of dark-adapted and light-adapted cones; the sensitivity cannot be restored to wild-type levels [94]. These experiments demonstrate a stronger $\mathrm{Ca}^{2+}$ feedback to $\mathrm{CNG}$ channels in cones compared to rods. 


\section{Outer segment: a specialized primary cilium}

Photoreceptor outer segments are strongly modified specialized primary cilia, sharing many general structural and biochemical features of cilia [77]. Outer segment stacked discs are arranged on the side of a microtubule-based axoneme, anchoring inside the inner segment through a connecting cilium and its basal body. Therefore, the connecting cilium, known as the transition zone in other cell types, connects outer and inner segment, mediating bi-directional protein trafficking [181]. Dysfunctions of primary cilia result in human disorders referred to as ciliopathies, which were reviewed elsewhere [11].

Outer segments are constantly bombarded by photons and their integrity is endangered by radical oxygen species. Since photoreceptors, like most neurons of the central nervous system, cannot be replaced, photoreceptors constantly rejuvenate themselves by renewing their outer segments. New discs are synthesized by ciliary membrane evagination at the base of the outer segment as the ciliary ectosomes, which then is elongated, flattened, and enclosed inside the outer segment [87, 173, $38,171]$. The tips of the outer segments, containing the oldest and potentially damaged membranes, are phagocytosed and digested by RPE cells. Although outer segment renewal/ shedding is essential for photoreceptor homeostasis and survival, molecular mechanisms underlying its regulation are still poorly understood.

Recent works on zebrafish have contributed significantly to our understanding of the molecular mechanisms behind photoreceptor outer segment shedding and renewal. The zebrafish lends itself ideally to transgenically label cellular structures or cells, as Willoughby and colleagues have used elegantly for the outer segment [205]. They devised a stable line with heat shock-inducible fluorescent membrane protein that allowed them to follow the renewal and shedding of the rod outer segments as an updated experimental approach to the classic radioactive labeling method [214]. This line was then used in a high-content small-molecule screens that among others identified an involvement of cyclooxygenase in outer segment growth, gamma secretase in outer segment shedding, and mTOR in RPE phagocytosis [25].

Some earlier studies demonstrated that disc shedding in frog and cat was initiated by light $[15,53]$. A recent zebrafish study using PDE6 inhibitors to block the visual transduction cascade mimicking constant dark conditions indeed inhibited rod outer segment shedding [24]. Interestingly, mammalian rod outer segment shedding remains in constant darkness, instead showing circadian clock controlling disc shedding mechanism [108, 185, 64, 74].

Given the nature of the outer segment, it comes as no surprise that many genes associated with intracellular and ciliary trafficking are involved in outer segment generation and maintenance.
The most abundant protein that needs to be shipped out to the outer segment is rhodopsin. Every second, around 70 rhodopsin molecules are trafficked from the inner to the outer segment [213, 204, 141]. Detailed studies of rhodopsin transport in frogs showed that RAB8, a small GTPase, coats rhodopsin-carrier vesicles and directs them to a selective barrier at the base of connecting cilium [139, 36]. In live imaging experiments in zebrafish, RAB8-directed rhodopsin trafficking in rods has been directly visualized in vivo [135]. The correct localization of RAB8 at the base of the outer segment is regulated by components of the connecting cilium itself, such as CC2D2A and further interaction partners, such as Ninl and MICAL3 [10, 12].

About $10 \%$ of outer segment is renewed every day in mammalian photoreceptors [108]. Therefore, intraflagellar transport (IFT), which contributes primarily to traffic visual transduction proteins into the outer segment, is important for outer segment development and structure [77]. IFT-B complex and kinesin motors mediate anterograde movement towards the distal outer segment, while IFT-A and dynein motors mediate retrograde movement towards the cell body [154].

A series of zebrafish studies contributed greatly to our understanding of the mechanism underlying IFT. Mutations affecting the IFT-B complex (IFT52, IFT57, IFT88, IFT172) lead to defects in outer segment formation and/or maintenance, finally resulting in both rod and cone degeneration [188, 41, 65]. Biochemical assays indicated that IFT20, a IFT-A member, requires IFT57 to associate with the IFT particle [97]. In another study, TNF receptor-associated factor 3 interacting protein 1 (TRAF3IP1) was shown to bind to IFT20. It can also interact with RAB8 via Rabaptin5, an endocytosis regulator. This demonstrates a connection between the IFT particle and the GTPase pathway, known to facilitate protein complex assembling [136].

Moreover, microtubular motors play an essential role in transporting IFT complexes. KIF17, kinesin-2 family member, is involved in ciliogenesis [206]. It is located all over zebrafish cones but concentrates at the basal body and the distal tip of the axoneme [13]. Knockdown of kif17 disrupts outer segment structure and mislocates visual transduction proteins [78]. Disc shedding is also promoted by KIF17 and eliminated in its absence [110].

\section{Ribbon synapses}

Non-spiking photoreceptors respond and adapt to a wide range of light intensities. The light-induced CNG channel closure generates the graded changes in membrane potential, which in turn regulates tonic neurotransmitter glutamate release at the presynaptic terminals $[175,163,187]$. This graded signaling is facilitated by specialized ribbon synapses, which hold a dense array of synaptic vesicles near active zones along 
their surface and were firstly identified by electron microscopy as electron dense structures in guinea pig rod synapses [169].

Work on zebrafish has helped to identify the key components of ribbon synapses and their function in signal transmission.

Ribeye is the most abundant protein in the synaptic ribbon [163]. In the zebrafish retina, both ribeyea and ribeyeb are present in the photoreceptors while ribeyea also shows expression in bipolar cells. Downregulation of ribeyea diminishes OKR and reduces ribbon length and number [198, 116].

Synaptojanin (Synj1) is a polyphosphoinositide phosphatase regulating clathrin-mediated endocytosis in conventional synapses [155]. A zebrafish synj1 null mutation (nrc) shows unanchored "floating" ribbons and reduced synaptic vesicles in cone but not rod synapses[189, 68], associated with defect in vision [4].

Photoreceptor L-type voltage-dependent calcium channels $\left(\mathrm{Ca}_{\mathrm{v}} 1.4\right)$ are located in the vicinity of synaptic ribbons and mediate exocytosis [187]. In darkness, they are opened by the depolarized photoreceptor membrane potential, resulting in calcium-dependent glutamate release. $\mathrm{Ca}_{\mathrm{v}} 1.4$ are heteromultimeric protein complexes comprising of a poreforming $\alpha_{1} \mathrm{~F}$ subunit, encoded by $C A C N A 1 F$, and accessory $\beta$ and $\alpha_{2} \delta$ subunits, encoded by $C A C N B 2$ and CACNA2D4, respectively. Mutations in $C A C N A 1 F$ gene result in X-linked congenital stationary night blindness type 2 and cone-rod dystrophy in human [16, 178]. Two paralogues, cacnalfa and cacnalfb are identified in zebrafish with cacnalfa being expressed in photoreceptors while cacnalfb only existing in the inner retina [80]. CACNA1Fa protein exclusively accumulates at the outer plexiform layer and its null mutants (wud) present thinner outer plexiform layer, defective ERG, completely absent of synaptic ribbons, and mislocalized Ribeyeb.

Mutations in human CACNA2D4 are related to autosomal recessive cone dystrophy, while rods in different $C A C N A 2 D 4$ knockout mouse lines are even more severely affected, showing missing or largely defective scotopic and photopic ERG response [208, 86, 71]. More recently, another study focused on zebrafish cacna2d4 encoding Cav1.4 $\alpha 2 \delta$ subunit [116]. cacna2d4 is duplicated in zebrafish as cacna2d $4 a$ and cacna $2 d 4 b$. Double KO shows reduced pore-forming CACNA1Fa expression and minor defects in both visual function and ribbon structure. The zebrafish $\mathrm{KO}$ model is associated with similar moderate phenotype in human patients, providing a comprehensive tool to study the related human eye disorders.

Zebrafish show a peculiar phenomenon of disassembled ribbon synapses at least in the larval retina during the night. At light onset, the presynaptic structure is rapidly reassembled for function [47]. This unusual mechanism may have evolved to save energy in rapidly growing larvae.

\section{Conclusion}

The zebrafish retina serves as an important model of cone photoreceptor and has already contributed significantly to our understanding of photoreceptor maintenance and function. With its ever-increasing toolbox of imaging and genetic techniques, it will continue to crucially help us further in investigating the outer retina and its diseases.

Acknowledgements Open Access funding provided by Universität Zürich.

Funding This work was supported by the Swiss National Science foundation (31003A_173083).

\section{Declarations}

Conflict of interest The authors declare no conflicts of interest.

Open Access This article is licensed under a Creative Commons Attribution 4.0 International License, which permits use, sharing, adaptation, distribution and reproduction in any medium or format, as long as you give appropriate credit to the original author(s) and the source, provide a link to the Creative Commons licence, and indicate if changes were made. The images or other third party material in this article are included in the article's Creative Commons licence, unless indicated otherwise in a credit line to the material. If material is not included in the article's Creative Commons licence and your intended use is not permitted by statutory regulation or exceeds the permitted use, you will need to obtain permission directly from the copyright holder. To view a copy of this licence, visit http://creativecommons.org/licenses/by/4.0/.

\section{References}

1. Ali MA (1971) Retinomotor response: characteristics and mechanisms. Vision Res 11:1225-1288. https://doi.org/10.1016/00426989(71)90010-1

2. Allison WT, Barthel LK, Skebo KM, Takechi M, Kawamura S, Raymond PA (2010) Ontogeny of cone photoreceptor mosaics in zebrafish. J Comp Neurol 518:4182-4195. https://doi.org/10. 1002/cne. 22447

3. Allison WT, Haimberger TJ, Hawryshyn CW, Temple SE (2004) Visual pigment composition in zebrafish: evidence for a rhodopsin-porphyropsin interchange system. Vis Neurosci 21: 945-952. https://doi.org/10.1017/S0952523804216145

4. Allwardt BA, Lall AB, Brockerhoff SE, Dowling JE (2001) Synapse formation is arrested in retinal photoreceptors of the zebrafish nrc mutant. J Neurosci 21:2330-2342

5. Alshamrani AA, Raddadi O, Schatz P, Lenzner S, Neuhaus C, Azzam E, Abdelkader E (2020) Severe retinitis pigmentosa phenotype associated with novel CNGB1 variants. Am J Ophthalmol Case Rep 19:100780. https://doi.org/10.1016/j.ajoc.2020.100780

6. Ames JB, Ishima R, Tanaka T, Gordon JI, Stryer L, Ikura M (1997) Molecular mechanics of calcium-myristoyl switches. Nature 389:198-202. https://doi.org/10.1038/38310

7. Amores A, Force A, Yan YL, Joly L, Amemiya C, Fritz A, Ho RK, Langeland J, Prince V, Wang YL, Westerfield M, Ekker M, Postlethwait JH (1998) Zebrafish hox clusters and vertebrate 
genome evolution. Science 282:1711-1714. https://oi.org/10. 1126/science.282.5394.1711

8. Angueyra JM, Kindt KS (2018) Leveraging zebrafish to study retinal degenerations. Front Cell Dev Biol 6:110. https://doi.org/ 10.3389/fcell.2018.00110

9. Aquila M, Dell'Orco D, Fries R, Koch KW, Rispoli G (2019) Incorporating phototransduction proteins in zebrafish green cone with pressure-polished patch pipettes. Biophys Chem 253: 106230. https://doi.org/10.1016/j.bpc.2019.106230

10. Bachmann-Gagescu R, Dona M, Hetterschijt L, Tonnaer E, Peters T, de Vrieze E, Mans DA, van Beersum SE, Phelps IG, Arts HH, Keunen JE, Ueffing M, Roepman R, Boldt K, Doherty D, Moens CB, Neuhauss SC, Kremer H, van Wijk E (2015) The Ciliopathy protein $\mathrm{CC} 2 \mathrm{D} 2 \mathrm{~A}$ associates with NINL and functions in RAB8MICAL3-regulated vesicle trafficking. PLoS Genet 11:e1005575. https://doi.org/10.1371/journal.pgen.1005575

11. Bachmann-Gagescu R, Neuhauss SC (2019) The photoreceptor cilium and its diseases. Curr Opin Genet Dev 56:22-33. https:// doi.org/10.1016/j.gde.2019.05.004

12. Bachmann-Gagescu R, Phelps IG, Stearns G, Link BA, Brockerhoff SE, Moens CB, Doherty D (2011) The ciliopathy gene $\operatorname{cc} 2 \mathrm{~d} 2 \mathrm{a}$ controls zebrafish photoreceptor outer segment development through a role in Rab8-dependent vesicle trafficking. Hum Mol Genet 20:4041-4055. https://doi.org/10.1093/hmg/ ddr332

13. Bader JR, Kusik BW, Besharse JC (2012) Analysis of KIF17 distal tip trafficking in zebrafish cone photoreceptors. Vision Res 75:37-43. https://doi.org/10.1016/j.visres.2012.10.009

14. Bareil C, Hamel CP, Delague V, Arnaud B, Demaille J, Claustres $M$ (2001) Segregation of a mutation in CNGB1 encoding the betasubunit of the rod cGMP-gated channel in a family with autosomal recessive retinitis pigmentosa. Hum Genet 108:328-334. https:// doi.org/10.1007/s004390100496

15. Basinger S, Hoffman R, Matthes M (1976) Photoreceptor shedding is initiated by light in the frog retina. Science 194:1074 1076. https://doi.org/10.1126/science.1086510

16. Bech-Hansen NT, Naylor MJ, Maybaum TA, Pearce WG, Koop B, Fishman GA, Mets M, Musarella MA, Boycott KM (1998) Loss-of-function mutations in a calcium-channel alpha1-subunit gene in Xp11.23 cause incomplete X-linked congenital stationary night blindness. Nat Genet 19:264-267. https://doi.org/10.1038/ 947

17. Berman DM, Wilkie TM, Gilman AG (1996) GAIP and RGS4 are GTPase-activating proteins for the Gi subfamily of $\mathrm{G}$ protein alpha subunits. Cell 86:445-452. https://doi.org/10.1016/s00928674(00)80117-8

18. Bibliowicz J, Tittle RK, Gross JM (2011) Toward a better understanding of human eye disease insights from the zebrafish, Danio rerio. Prog Mol Biol Transl Sci 100:287-330. https://doi.org/10. 1016/B978-0-12-384878-9.00007-8

19. Bradley J, Reisert J, Frings S (2005) Regulation of cyclic nucleotide-gated channels. Curr Opin Neurobiol 15:343-349. https://doi.org/10.1016/j.conb.2005.05.014

20. Branchek T, Bremiller R (1984) The development of photoreceptors in the zebrafish. Brachydanio rerio. I. Structure. J Comp Neurol 224:107-115. https://doi.org/10.1002/cne.902240109

21. Brockerhoff SE, Rieke F, Matthews HR, Taylor MR, Kennedy B, Ankoudinova I, Niemi GA, Tucker CL, Xiao M, Cilluffo MC, Fain GL, Hurley JB (2003) Light stimulates a transducinindependent increase of cytoplasmic $\mathrm{Ca} 2+$ and suppression of current in cones from the zebrafish mutant nof. J Neurosci 23: 470-480

22. Burns ME, Baylor DA (2001) Activation, deactivation, and adaptation in vertebrate photoreceptor cells. Annu Rev Neurosci 24: 779-805. https://doi.org/10.1146/annurev.neuro.24.1.779
23. Cameron DA (2002) Mapping absorbance spectra, cone fractions, and neuronal mechanisms to photopic spectral sensitivity in the zebrafish. Vis Neurosci 19:365-372. https://doi.org/10.1017/ s0952523802192121

24. Campbell LJ, Jensen AM (2017) Phosphodiesterase inhibitors sildenafil and vardenafil reduce zebrafish rod photoreceptor outer segment shedding. Invest Ophthalmol Vis Sci 58:5604-5615. https://doi.org/10.1167/iovs.17-21958

25. Campbell LJ, West MC, Jensen AM (2018) A high content, small molecule screen identifies candidate molecular pathways that regulate rod photoreceptor outer segment renewal. Sci Rep 8:14017. https://doi.org/10.1038/s41598-018-32336-y

26. Cavallari N, Frigato E, Vallone D, Fröhlich N, Lopez-Olmeda JF, Foà A, Berti R, Sánchez-Vázquez FJ, Bertolucci C, Foulkes NS (2011) A blind circadian clock in cavefish reveals that opsins mediate peripheral clock photoreception. PLoS Biol 9:e1001142. https://doi.org/10.1371/journal.pbio.1001142

27. Chang B, Grau T, Dangel S, Hurd R, Jurklies B, Sener EC, Andreasson S, Dollfus H, Baumann B, Bolz S, Artemyev N, Kohl S, Heckenlively J, Wissinger B (2009) A homologous genetic basis of the murine cpfll mutant and human achromatopsia linked to mutations in the PDE6C gene. Proc Natl Acad Sci U S A 106:19581-19586. https://doi.org/10.1073/pnas.0907720106

28. Chen H, Leung T, Giger KE, Stauffer AM, Humbert JE, Sinha S, Horstick EJ, Hansen CA, Robishaw JD (2007) Expression of the $\mathrm{G}$ protein gammaT1 subunit during zebrafish development. Gene Expr Patterns 7:574-583. https://doi.org/10.1016/j.modgep.2007. 01.003

29. Chen J, Woodruff ML, Wang T, Concepcion FA, Tranchina D, Fain GL (2010) Channel modulation and the mechanism of light adaptation in mouse rods. J Neurosci 30:16232-16240. https://doi. org/10.1523/JNEUROSCI.2868-10.2010

30. Chinen A, Hamaoka T, Yamada Y, Kawamura S (2003) Gene duplication and spectral diversification of cone visual pigments of zebrafish. Genetics 163:663-675

31. Chrispell JD, Dong E, Osawa S, Liu J, Cameron DJ, Weiss ER (2018) Grk1b and Grk7a both contribute to the recovery of the isolated cone photoresponse in larval zebrafish. Invest Ophthalmol Vis Sci 59:5116-5124. https://doi.org/10.1167/iovs. 18-24455

32. Cote RH (2004) Characteristics of photoreceptor PDE (PDE6): similarities and differences to PDE5. Int J Impot Res 16(Suppl 1):S28-S33. https://doi.org/10.1038/sj.ijir.3901212

33. Cowan CW, Fariss RN, Sokal I, Palczewski K, Wensel TG (1998) High expression levels in cones of RGS9, the predominant GTPase accelerating protein of rods. Proc Natl Acad Sci U S A 95:5351-5356. https://doi.org/10.1073/pnas.95.9.5351

34. Davies WI, Tamai TK, Zheng L, Fu JK, Rihel J, Foster RG, Whitmore D, Hankins MW (2015) An extended family of novel vertebrate photopigments is widely expressed and displays a diversity of function. Genome Res 25:1666-1679. https://doi.org/ $10.1101 /$ gr. 189886.115

35. Davies WI, Zheng L, Hughes S, Tamai TK, Turton M, Halford S, Foster RG, Whitmore D, Hankins MW (2011) Functional diversity of melanopsins and their global expression in the teleost retina. Cell Mol Life Sci 68:4115-4132. https://doi.org/10.1007/ s00018-011-0785-4

36. Deretic D, Huber LA, Ransom N, Mancini M, Simons K, Papermaster DS (1995) rab8 in retinal photoreceptors may participate in rhodopsin transport and in rod outer segment disk morphogenesis. J Cell Sci 108(Pt 1):215-224

37. Deveau C, Jiao X, Suzuki SC, Krishnakumar A, Yoshimatsu T, Hejtmancik JF, Nelson RF (2020) Thyroid hormone receptor beta mutations alter photoreceptor development and function in Danio rerio (zebrafish). PLoS Genet 16:e1008869. https://doi.org/10. 1371/journal.pgen.1008869 
38. Ding JD, Salinas RY, Arshavsky VY (2015) Discs of mammalian rod photoreceptors form through the membrane evagination mechanism. J Cell Biol 211:495-502. https://doi.org/10.1083/ jcb.201508093

39. Dizhoor AM, Lowe DG, Olshevskaya EV, Laura RP, Hurley JB (1994) The human photoreceptor membrane guanylyl cyclase, RetGC, is present in outer segments and is regulated by calcium and a soluble activator. Neuron 12:1345-1352. https://doi.org/10. 1016/0896-6273(94)90449-9

40. Dizhoor AM, Ray S, Kumar S, Niemi G, Spencer M, Brolley D, Walsh KA, Philipov PP, Hurley JB, Stryer L (1991) Recoverin: a calcium sensitive activator of retinal rod guanylate cyclase. Science 251:915-918

41. Doerre G, Malicki J (2002) Genetic analysis of photoreceptor cell development in the zebrafish retina. Mech Dev 110:125-138. https://doi.org/10.1016/s0925-4773(01)00571-8

42. Dryja TP, Finn JT, Peng YW, McGee TL, Berson EL, Yau KW (1995) Mutations in the gene encoding the alpha subunit of the rod cGMP-gated channel in autosomal recessive retinitis pigmentosa. Proc Natl Acad Sci U S A 92:10177-10181. https://doi.org/10. 1073/pnas.92.22.10177

43. Dryja TP, McGee TL, Reichel E, Hahn LB, Cowley GS, Yandell DW, Sandberg MA, Berson EL (1990) A point mutation of the rhodopsin gene in one form of retinitis pigmentosa. Nature 343: 364-366. https://doi.org/10.1038/343364a0

44. Ebrey T, Koutalos Y (2001) Vertebrate photoreceptors. Prog Retin Eye Res 20:49-94. https://doi.org/10.1016/s1350-9462(00) 00014-8

45. Elbers D, Scholten A, Koch KW (2018) Zebrafish recoverin isoforms display differences in calcium switch mechanisms. Front Mol Neurosci 11:355. https://doi.org/10.3389/fnmol.2018.00355

46. Elias RV, Sezate SS, Cao W, McGinnis JF (2004) Temporal kinetics of the light/dark translocation and compartmentation of arrestin and alpha-transducin in mouse photoreceptor cells. Mol Vis 10:672-681

47. Emran F, Rihel J, Adolph AR, Dowling JE (2010) Zebrafish larvae lose vision at night. Proc Natl Acad Sci U S A 107:6034 6039. https://doi.org/10.1073/pnas.0914718107

48. Enright JM, Toomey MB, Sato SY, Temple SE, Allen JR, Fujiwara R, Kramlinger VM, Nagy LD, Johnson KM, Xiao Y, How MJ, Johnson SL, Roberts NW, Kefalov VJ, Guengerich FP, Corbo JC (2015) Cyp27c1 red-shifts the spectral sensitivity of photoreceptors by converting vitamin A1 into A2. Curr Biol 25: 3048-3057. https://doi.org/10.1016/j.cub.2015.10.018

49. Fadool JM (2003) Development of a rod photoreceptor mosaic revealed in transgenic zebrafish. Dev Biol 258:277-290. https:// doi.org/10.1016/s0012-1606(03)00125-8

50. Fain GL, Matthews HR, Cornwall MC, Koutalos Y (2001) Adaptation in vertebrate photoreceptors. Physiol Rev 81:117151. https://doi.org/10.1152/physrev.2001.81.1.117

51. Farahbakhsh ZT, Hideg K, Hubbell WL (1993) Photoactivated conformational changes in rhodopsin: a time-resolved spin label study. Science 262:1416-1419. https://doi.org/10.1126/science. 8248781

52. Farrens DL, Altenbach C, Yang K, Hubbell WL, Khorana HG (1996) Requirement of rigid-body motion of transmembrane helices for light activation of rhodopsin. Science 274:768-770. https:// doi.org/10.1126/science.274.5288.768

53. Fisher SK, Pfeffer BA, Anderson DH (1983) Both rod and cone disc shedding are related to light onset in the cat. Invest Ophthalmol Vis Sci 24:844-856

54. Fries R, Scholten A, Säftel W, Koch KW (2012) Operation profile of zebrafish guanylate cyclase-activating protein 3. J Neurochem 121:54-65. https://doi.org/10.1111/j.1471-4159.2011.07643.x
55. Fries R, Scholten A, Säftel W, Koch KW (2013) Zebrafish guanylate cyclase type 3 signaling in cone photoreceptors. PLoS One 8:e69656. https://doi.org/10.1371/journal.pone.0069656

56. Frøland Steindal IA, Whitmore D (2019) Circadian clocks in fishwhat have we learned so far? Biology (Basel) 8. https://doi.org/10. 3390/biology8010017

57. Fu Y, Yau KW (2007) Phototransduction in mouse rods and cones. Pflugers Arch 454:805-819. https://doi.org/10.1007/ s00424-006-0194-y

58. Fuchs S, Nakazawa M, Maw M, Tamai M, Oguchi Y, Gal A (1995) A homozygous 1-base pair deletion in the arrestin gene is a frequent cause of Oguchi disease in Japanese. Nat Genet 10: 360-362. https://doi.org/10.1038/ng0795-360

59. Georgiou M, Robson AG, Singh N, Pontikos N, Kane T, Hirji N, Ripamonti C, Rotsos T, Dubra A, Kalitzeos A, Webster AR, Carroll J, Michaelides M (2019) Deep phenotyping of PDE6Cassociated achromatopsia. Invest Ophthalmol Vis Sci 60:51125123. https://doi.org/10.1167/iovs.19-27761

60. Gesemann M, Neuhauss SCF (2020) Selective gene loss of visual and olfactory guanylyl cyclase genes following the two rounds of vertebrate-specific whole-genome duplications. Genome Biol Evol 12:2153-2167. https://doi.org/10.1093/gbe/evaa192

61. Gestri G, Link BA, Neuhauss SC (2012) The visual system of zebrafish and its use to model human ocular diseases. Dev Neurobiol 72:302-327. https://doi.org/10.1002/dneu.20919

62. Gillespie PG, Beavo JA (1988) Characterization of a bovine cone photoreceptor phosphodiesterase purified by cyclic GMPsepharose chromatography. J Biol Chem 263:8133-8141

63. Glasauer SM, Neuhauss SC (2014) Whole-genome duplication in teleost fishes and its evolutionary consequences. Mol Genet Genomics 289:1045-1060. https://doi.org/10.1007/s00438-0140889-2

64. Grace MS, Wang LM, Pickard GE, Besharse JC, Menaker M (1996) The tau mutation shortens the period of rhythmic photoreceptor outer segment disk shedding in the hamster. Brain Res 735: 93-100. https://doi.org/10.1016/0006-8993(96)00600-2

65. Gross JM, Perkins BD, Amsterdam A, Egaña A, Darland T, Matsui JI, Sciascia S, Hopkins N, Dowling JE (2005) Identification of zebrafish insertional mutants with defects in visual system development and function. Genetics 170:245-261. https://doi.org/10.1534/genetics.104.039727

66. Hárosi FI (1994) An analysis of two spectral properties of vertebrate visual pigments. Vision Res 34:1359-1367. https://oi.org/ 10.1016/0042-6989(94)90134-1

67. Hodel C, Neuhauss SC, Biehlmaier O (2006) Time course and development of light adaptation processes in the outer zebrafish retina. Anat Rec A Discov Mol Cell Evol Biol 288:653-662. https://doi.org/10.1002/ar.a.20329

68. Holzhausen LC, Lewis AA, Cheong KK, Brockerhoff SE (2009) Differential role for synaptojanin 1 in rod and cone photoreceptors. J Comp Neurol 517:633-644. https://doi.org/10.1002/cne. 22176

69. Howe K, Clark MD, Torroja CF, Torrance J, Berthelot C, Muffato M, Collins JE, Humphray S, McLaren K, Matthews L, McLaren S, Sealy I, Caccamo M, Churcher C, Scott C, Barrett JC, Koch R, Rauch GJ, White S, Chow W, Kilian B, Quintais LT, GuerraAssunção JA, Zhou Y, Gu Y, Yen J, Vogel JH, Eyre T, Redmond S, Banerjee R, Chi J, Fu B, Langley E, Maguire SF, Laird GK, Lloyd D, Kenyon E, Donaldson S, Sehra H, AlmeidaKing J, Loveland J, Trevanion S, Jones M, Quail M, Willey D, Hunt A, Burton J, Sims S, McLay K, Plumb B, Davis J, Clee C, Oliver K, Clark R, Riddle C, Elliot D, Eliott D, Threadgold G, Harden G, Ware D, Begum S, Mortimore B, Mortimer B, Kerry G, Heath P, Phillimore B, Tracey A, Corby N, Dunn M, Johnson C, Wood J, Clark S, Pelan S, Griffiths G, Smith M, Glithero R, Howden P, Barker N, Lloyd C, Stevens C, Harley J, Holt K, 
Panagiotidis G, Lovell J, Beasley H, Henderson C, Gordon D, Auger K, Wright D, Collins J, Raisen C, Dyer L, Leung K, Robertson L, Ambridge K, Leongamornlert D, McGuire S, Gilderthorp R, Griffiths C, Manthravadi D, Nichol S, Barker G, Whitehead S, Kay M, Brown J, Murnane C, Gray E, Humphries M, Sycamore N, Barker D, Saunders D, Wallis J, Babbage A, Hammond S, Mashreghi-Mohammadi M, Barr L, Martin S, Wray P, Ellington A, Matthews N, Ellwood M, Woodmansey R, Clark G, Cooper J, Tromans A, Grafham D, Skuce C, Pandian R, Andrews R, Harrison E, Kimberley A, Garnett J, Fosker N, Hall R, Garner P, Kelly D, Bird C, Palmer S, Gehring I, Berger A, Dooley CM, Ersan-Ürün Z, Eser C, Geiger H, Geisler M, Karotki L, Kirn A, Konantz J, Konantz M, Oberländer M, Rudolph-Geiger S, Teucke M, Lanz C, Raddatz G, Osoegawa K, Zhu B, Rapp A, Widaa S, Langford C, Yang F, Schuster SC, Carter NP, Harrow J, Ning Z, Herrero J, Searle SM, Enright A, Geisler R, Plasterk RH, Lee C, Westerfield M, de Jong PJ, Zon LI, Postlethwait JH, Nüsslein-Volhard C, Hubbard TJ, Roest Crollius H, Rogers J, Stemple DL (2013) The zebrafish reference genome sequence and its relationship to the human genome. Nature 496: 498-503. https://doi.org/10.1038/nature12111

70. Hsu YT, Molday RS (1993) Modulation of the cGMP-gated channel of rod photoreceptor cells by calmodulin. Nature 361:76-79. https://doi.org/10.1038/361076a0

71. Huang L, Zhang Q, Li S, Guan L, Xiao X, Zhang J, Jia X, Sun W, Zhu Z, Gao Y, Yin Y, Wang P, Guo X, Wang J (2013) Exome sequencing of 47 chinese families with cone-rod dystrophy: mutations in 25 known causative genes. PLoS One 8:e65546. https:// doi.org/10.1371/journal.pone.0065546

72. Huang SH, Pittler SJ, Huang X, Oliveira L, Berson EL, Dryja TP (1995) Autosomal recessive retinitis pigmentosa caused by mutations in the alpha subunit of rod cGMP phosphodiesterase. Nat Genet 11:468-471. https://doi.org/10.1038/ng1295-468

73. Hubbard R, Kropf A (1958) The action of light on rhodopsin. Proc Natl Acad Sci U S A 44:130-139. https://doi.org/10.1073/pnas. 44.2 .130

74. Ikarashi R, Akechi H, Kanda Y, Ahmad A, Takeuchi K, Morioka E, Sugiyama T, Ebisawa T, Ikeda M (2017) Regulation of molecular clock oscillations and phagocytic activity via muscarinic $\mathrm{Ca}$. Sci Rep 7:44175. https://doi.org/10.1038/srep44175

75. Imanishi Y, Li N, Sokal I, Sowa ME, Lichtarge O, Wensel TG, Saperstein DA, Baehr W, Palczewski K (2002) Characterization of retinal guanylate cyclase-activating protein 3 (GCAP3) from zebrafish to man. Eur J Neurosci 15:63-78. https://doi.org/10. 1046/j.0953-816x.2001.01835.x

76. Imanishi Y, Yang L, Sokal I, Filipek S, Palczewski K, Baehr W (2004) Diversity of guanylate cyclase-activating proteins (GCAPs) in teleost fish: characterization of three novel GCAPs (GCAP4, GCAP5, GCAP7) from zebrafish (Danio rerio) and prediction of eight GCAPs (GCAP1-8) in pufferfish (Fugu rubripes). J Mol Evol 59:204-217. https://doi.org/10.1007/s00239-0042614-y

77. Insinna C, Besharse JC (2008) Intraflagellar transport and the sensory outer segment of vertebrate photoreceptors. Dev Dyn 237:1982-1992. https://doi.org/10.1002/dvdy.21554

78. Insinna C, Pathak N, Perkins B, Drummond I, Besharse JC (2008) The homodimeric kinesin, Kif17, is essential for vertebrate photoreceptor sensory outer segment development. Dev Biol 316: 160-170. https://doi.org/10.1016/j.ydbio.2008.01.025

79. Iribarne M, Nishiwaki Y, Nakamura S, Araragi M, Oguri E, Masai I (2017) Aipl1 is required for cone photoreceptor function and survival through the stability of Pde6c and Gc3 in zebrafish. Sci Rep 7:45962. https://doi.org/10.1038/srep45962

80. Jia S, Muto A, Orisme W, Henson HE, Parupalli C, Ju B, Baier H, Taylor MR (2014) Zebrafish Cacna1fa is required for cone photoreceptor function and synaptic ribbon formation. Hum Mol Genet 23:2981-2994. https://doi.org/10.1093/hmg/ddu009

81. Kaupp UB, Seifert R (2002) Cyclic nucleotide-gated ion channels. Physiol Rev 82:769-824. https://doi.org/10.1152/physrev.00008. 2002

82. Kawamura S (1993) Rhodopsin phosphorylation as a mechanism of cyclic GMP phosphodiesterase regulation by S-modulin. Nature 362:855-857. https://doi.org/10.1038/362855a0

83. Kawamura S, Kuwata O, Yamada M, Matsuda S, Hisatomi O, Tokunaga F (1996) Photoreceptor protein s26, a cone homologue of S-modulin in frog retina. J Biol Chem 271:21359-21364

84. Kennedy B, Malicki J (2009) What drives cell morphogenesis: a look inside the vertebrate photoreceptor. Dev Dyn 238:21152138. https://doi.org/10.1002/dvdy.22010

85. Kennedy MJ, Dunn FA, Hurley JB (2004) Visual pigment phosphorylation but not transducin translocation can contribute to light adaptation in zebrafish cones. Neuron 41:915-928

86. Kerov V, Laird JG, Joiner ML, Knecht S, Soh D, Hagen J, Gardner SH, Gutierrez W, Yoshimatsu T, Bhattarai S, Puthussery T, Artemyev NO, Drack AV, Wong RO, Baker SA, Lee A (2018) $\alpha_{2} \delta-4$ is required for the molecular and structural organization of rod and cone photoreceptor synapses. J Neurosci 38:6145-6160. https://doi.org/10.1523/JNEUROSCI.3818-16. 2018

87. Kinney MS, Fisher SK (1978) The photoreceptors and pigment epithelium of the larval xenopus retina: morphogenesis and outer segment renewal. Proc R Soc Lond B Biol Sci 201:149-167. https://doi.org/10.1098/rspb.1978.0037

88. Koch KW, Duda T, Sharma RK (2002) Photoreceptor specific guanylate cyclases in vertebrate phototransduction. Mol Cell Biochem 230:97-106

89. Koch KW, Duda T, Sharma RK (2010) Ca(2+)-modulated visionlinked ROS-GC guanylate cyclase transduction machinery. Mol Cell Biochem 334:105-115. https://doi.org/10.1007/s11010-0090330-z

90. Koch KW, Stryer L (1988) Highly cooperative feedback control of retinal rod guanylate cyclase by calcium ions. Nature 334:64 66. https://doi.org/10.1038/334064a0

91. Kohl S, Baumann B, Rosenberg T, Kellner U, Lorenz B, Vadalà M, Jacobson SG, Wissinger B (2002) Mutations in the cone photoreceptor G-protein alpha-subunit gene GNAT2 in patients with achromatopsia. Am J Hum Genet 71:422-425. https://doi.org/10. $1086 / 341835$

92. Kolb H, Fernandez E, Nelson R (1995) Webvision: the organization of the retina and visual system. In. doi:NBK482309

93. Kondo H, Qin M, Mizota A, Kondo M, Hayashi H, Hayashi K, Oshima K, Tahira T (2004) A homozygosity-based search for mutations in patients with autosomal recessive retinitis pigmentosa, using microsatellite markers. Invest Ophthalmol Vis Sci 45:4433-4439. https://doi.org/10.1167/iovs.04-0544

94. Korenbrot JI, Mehta M, Tserentsoodol N, Postlethwait JH, Rebrik TI (2013) EML1 (CNG-modulin) controls light sensitivity in darkness and under continuous illumination in zebrafish retinal cone photoreceptors. J Neurosci 33:17763-17776. https://doi.org/10. 1523/JNEUROSCI.2659-13.2013

95. Koutalos Y, Nakatani K, Yau KW (1995) The cGMPphosphodiesterase and its contribution to sensitivity regulation in retinal rods. J Gen Physiol 106:891-921. https://doi.org/10. 1085/jgp.106.5.891

96. Krispel CM, Chen D, Melling N, Chen YJ, Martemyanov KA, Quillinan N, Arshavsky VY, Wensel TG, Chen CK, Burns ME (2006) RGS expression rate-limits recovery of rod photoresponses. Neuron 51:409-416. https://doi.org/10.1016/j. neuron.2006.07.010

97. Krock BL, Perkins BD (2008) The intraflagellar transport protein IFT57 is required for cilia maintenance and regulates IFT-particle- 
kinesin-II dissociation in vertebrate photoreceptors. J Cell Sci 121: 1907-1915. https://doi.org/10.1242/jcs.029397

98. Kühn H, Hall SW, Wilden U (1984) Light-induced binding of 48$\mathrm{kDa}$ protein to photoreceptor membranes is highly enhanced by phosphorylation of rhodopsin. FEBS Lett 176:473-478. https:// doi.org/10.1016/0014-5793(84)81221-1

99. Lagman D, Callado-Pérez A, Franzén IE, Larhammar D, Abalo XM (2015) Transducin duplicates in the zebrafish retina and pineal complex: differential specialisation after the teleost tetraploidisation. PLoS One 10:e121330. https://doi.org/10. 1371/journal.pone. 0121330

100. Lagman D, Franzén IE, Eggert J, Larhammar D, Abalo XM (2016) Evolution and expression of the phosphodiesterase 6 genes unveils vertebrate novelty to control photosensitivity. BMC Evol Biol 16:124. https://doi.org/10.1186/s12862-016-0695-z

101. Lagnado L, Cervetto L, McNaughton PA (1992) Calcium homeostasis in the outer segments of retinal rods from the tiger salamander. J Physiol 455:111-142. https://doi.org/10.1113/jphysiol. 1992.sp019293

102. Lamb TD (2013) Evolution of phototransduction, vertebrate photoreceptors and retina. Prog Retin Eye Res 36:52-119. https://doi. org/10.1016/j.preteyeres.2013.06.001

103. Lamb TD, Hunt DM (2018) Evolution of the calcium feedback steps of vertebrate phototransduction. Open Biol 8. https://doi.org/ 10.1098/rsob.180119

104. Lamb TD, Patel HR, Chuah A, Hunt DM (2018) Evolution of the shut-off steps of vertebrate phototransduction. Open Biol 8 . https://doi.org/10.1098/rsob.170232

105. Lamb TD, Pugh EN (2006) Phototransduction, dark adaptation, and rhodopsin regeneration the proctor lecture. Invest Ophthalmol Vis Sci 47:5137-5152. https://doi.org/10.1167/iovs.06-0849

106. Larhammar D, Nordström K, Larsson TA (2009) Evolution of vertebrate rod and cone phototransduction genes. Philos Trans R Soc Lond B Biol Sci 364:2867-2880. https://doi.org/10.1098/rstb. 2009.0077

107. Larison KD, Bremiller R (1990) Early onset of phenotype and cell patterning in the embryonic zebrafish retina. Development 109: 567-576

108. LaVail MM (1976) Rod outer segment disk shedding in rat retina: relationship to cyclic lighting. Science 194:1071-1074. https:// doi.org/10.1126/science.982063

109. Leung YT, Fain GL, Matthews HR (2007) Simultaneous measurement of current and calcium in the ultraviolet-sensitive cones of zebrafish. J Physiol 579:15-27. https://doi.org/10.1113/jphysiol. 2006.120162

110. Lewis TR, Kundinger SR, Link BA, Insinna C, Besharse JC (2018) Kif17 phosphorylation regulates photoreceptor outer segment turnover. BMC Cell Biol 19:25. https://doi.org/10.1186/ s12860-018-0177-9

111. Li H, Chuang AZ, O’Brien J (2009) Photoreceptor coupling is controlled by connexin 35 phosphorylation in zebrafish retina. $\mathrm{J}$ Neurosci 29:15178-15186. https://doi.org/10.1523/JNEUROSCI. 3517-09.2009

112. Li XF, Kiedrowski L, Tremblay F, Fernandez FR, Perizzolo M, Winkfein RJ, Turner RW, Bains JS, Rancourt DE, Lytton J (2006) Importance of $\mathrm{K}+$-dependent $\mathrm{Na}+\mathrm{Ca} 2$ +-exchanger 2 , $\mathrm{NCKX} 2$, in motor learning and memory. J Biol Chem 281:6273-6282. https:// doi.org/10.1074/jbc.M512137200

113. Link BA, Collery RF (2015) Zebrafish models of retinal disease. Annu Rev Vis Sci 1:125-153. https://doi.org/10.1146/annurevvision-082114-035717

114. Lobanova ES, Herrmann R, Finkelstein S, Reidel B, Skiba NP, Deng WT, Jo R, Weiss ER, Hauswirth WW, Arshavsky VY (2010) Mechanistic basis for the failure of cone transducin to translocate: why cones are never blinded by light. J Neurosci 30: 6815-6824. https://doi.org/10.1523/JNEUROSCI.0613-10.2010
115. Loew ER, Dartnall HJ (1976) Vitamin A1/A2-based visual pigment mixtures in cones of the rudd. Vision Res 16:891-896. https://doi.org/10.1016/0042-6989(76)90217-0

116. Lv C, Gould TJ, Bewersdorf J, Zenisek D (2012) High-resolution optical imaging of zebrafish larval ribbon synapse protein RIBEYE, RIM2, and CaV 1.4 by stimulation emission depletion microscopy. Microsc Microanal 18:745-752. https://doi.org/10. 1017/S1431927612000268

117. Lyubarsky AL, Chen C, Simon MI, Pugh EN (2000) Mice lacking G-protein receptor kinase 1 have profoundly slowed recovery of cone-driven retinal responses. J Neurosci 20:2209-2217

118. Ma EY, Lewis A, Barabas P, Stearns G, Suzuki S, Krizaj D, Brockerhoff SE (2013) Loss of Pde6 reduces cell body $\mathrm{Ca}(2+)$ transients within photoreceptors. Cell Death Dis 4:e797. https:// doi.org/10.1038/cddis.2013.332

119. Mackin RD, Frey RA, Gutierrez C, Farre AA, Kawamura S, Mitchell DM, Stenkamp DL (2019) Endocrine regulation of multichromatic color vision. Proc Natl Acad Sci U S A 116: 16882-16891. https://doi.org/10.1073/pnas.1904783116

120. Matthews HR, Murphy RL, Fain GL, Lamb TD (1988) Photoreceptor light adaptation is mediated by cytoplasmic calcium concentration. Nature 334:67-69. https://doi.org/10.1038/ $334067 \mathrm{a} 0$

121. Matthews HR, Sampath AP (2010) Photopigment quenching is $\mathrm{Ca} 2+$ dependent and controls response duration in salamander L-cone photoreceptors. J Gen Physiol 135:355-366. https://doi. org/10.1085/jgp.200910394

122. McLaughlin ME, Sandberg MA, Berson EL, Dryja TP (1993) Recessive mutations in the gene encoding the beta-subunit of rod phosphodiesterase in patients with retinitis pigmentosa. Nat Genet 4:130-134. https://doi.org/10.1038/ng0693-130

123. Meier A, Nelson R, Connaughton VP (2018) Color processing in zebrafish retina. Front Cell Neurosci 12:327. https://doi.org/10. 3389/fncel.2018.00327

124. Menger GJ, Koke JR, Cahill GM (2005) Diurnal and circadian retinomotor movements in zebrafish. Vis Neurosci 22:203-209. https://doi.org/10.1017/S0952523805222083

125. Michalakis S, Becirovic E, Biel M (2018) Retinal cyclic nucleotide-gated channels: from pathophysiology to therapy. Int J Mol Sci:19. https://doi.org/10.3390/ijms19030749

126. Molday RS, Moritz OL (2015) Photoreceptors at a glance. J Cell Sci 128:4039-4045. https://doi.org/10.1242/jcs.175687

127. Muto A, Orger MB, Wehman AM, Smear MC, Kay JN, PageMcCaw PS, Gahtan E, Xiao T, Nevin LM, Gosse NJ, Staub W, Finger-Baier K, Baier H (2005) Forward genetic analysis of visual behavior in zebrafish. PLoS Genet 1:e66. https://doi.org/10.1371/ journal.pgen.0010066

128. Naeem MA, Chavali VR, Ali S, Iqbal M, Riazuddin S, Khan SN, Husnain T, Sieving PA, Ayyagari R, Hejtmancik JF, Riazuddin SA (2012) GNAT1 associated with autosomal recessive congenital stationary night blindness. Invest Ophthalmol Vis Sci 53:13531361. https://doi.org/10.1167/iovs.11-8026

129. Nakatani K, Yau KW (1988) Calcium and light adaptation in retinal rods and cones. Nature 334:69-71. https://doi.org/10. $1038 / 334069 \mathrm{a} 0$

130. Nathans J, Piantanida TP, Eddy RL, Shows TB, Hogness DS (1986) Molecular genetics of inherited variation in human color vision. Science 232:203-210. https://doi.org/10.1126/science. 3485310

131. Niklaus S, Neuhauss SCF (2017) Genetic approaches to retinal research in zebrafish. J Neurogenet 31:70-87. https://doi.org/10. 1080/01677063.2017.1343316

132. Nikonov SS, Brown BM, Davis JA, Zuniga FI, Bragin A, Pugh EN, Craft CM (2008) Mouse cones require an arrestin for normal inactivation of phototransduction. Neuron 59:462-474. https:// doi.org/10.1016/j.neuron.2008.06.011 
133. Nishiguchi KM, Sandberg MA, Kooijman AC, Martemyanov KA, Pott JW, Hagstrom SA, Arshavsky VY, Berson EL, Dryja TP (2004) Defects in RGS9 or its anchor protein R9AP in patients with slow photoreceptor deactivation. Nature 427:75-78. https:// doi.org/10.1038/nature02170

134. Nishiwaki Y, Komori A, Sagara H, Suzuki E, Manabe T, Hosoya T, Nojima Y, Wada H, Tanaka H, Okamoto H, Masai I (2008) Mutation of cGMP phosphodiesterase 6alpha'-subunit gene causes progressive degeneration of cone photoreceptors in zebrafish. Mech Dev 125:932-946. https://doi.org/10.1016/j.mod.2008.09. 001

135. Ojeda Naharros I, Gesemann M, Mateos JM, Barmettler G, Forbes A, Ziegler U, Neuhauss SCF, Bachmann-Gagescu R (2017) Lossof-function of the ciliopathy protein $\mathrm{Cc} 2 \mathrm{~d} 2 \mathrm{a}$ disorganizes the vesicle fusion machinery at the periciliary membrane and indirectly affects Rab8-trafficking in zebrafish photoreceptors. PLoS Genet 13:e1007150. https://doi.org/10.1371/journal.pgen.1007150

136. Omori Y, Zhao C, Saras A, Mukhopadhyay S, Kim W, Furukawa T, Sengupta P, Veraksa A, Malicki J (2008) Elipsa is an early determinant of ciliogenesis that links the IFT particle to membrane-associated small GTPase Rab8. Nat Cell Biol 10: 437-444. https://doi.org/10.1038/ncb1706

137. Paillart C, Winkfein RJ, Schnetkamp PP, Korenbrot JI (2007) Functional characterization and molecular cloning of the K+-dependent $\mathrm{Na}+\mathrm{Ca} 2+$ exchanger in intact retinal cone photoreceptors. J Gen Physiol 129:1-16. https://doi.org/10.1085/jgp. 200609652

138. Palczewski K, Polans AS, Baehr W, Ames JB (2000) Ca(2+)binding proteins in the retina: structure, function, and the etiology of human visual diseases. Bioessays 22:337-350. https://doi.org/ 10.1002/(SICI)1521-1878(200004)22:4<337::AID-BIES4>3.0. $\mathrm{CO} ; 2-\mathrm{Z}$

139. Papermaster DS, Schneider BG, Besharse JC (1985) Vesicular transport of newly synthesized opsin from the Golgi apparatus toward the rod outer segment. Ultrastructural immunocytochemical and autoradiographic evidence in Xenopus retinas. Invest Ophthalmol Vis Sci 26:1386-1404

140. Payne AM, Downes SM, Bessant DA, Taylor R, Holder GE, Warren MJ, Bird AC, Bhattacharya SS (1998) A mutation in guanylate cyclase activator 1A (GUCA1A) in an autosomal dominant cone dystrophy pedigree mapping to a new locus on chromosome 6p21.1. Hum Mol Genet 7:273-277. https://doi.org/10. 1093/hmg/7.2.273

141. Pearring JN, Salinas RY, Baker SA, Arshavsky VY (2013) Protein sorting, targeting and trafficking in photoreceptor cells. Prog Retin Eye Res 36:24-51. https://doi.org/10.1016/j.preteyeres.2013.03. 002

142. Perrault I, Rozet JM, Gerber S, Ghazi I, Ducroq D, Souied E, Leowski C, Bonnemaison M, Dufier JL, Munnich A, Kaplan J (2000) Spectrum of retGC1 mutations in Leber's congenital amaurosis. Eur J Hum Genet 8:578-582. https://doi.org/10.1038/sj. ejhg. 5200503

143. Prinsen CF, Szerencsei RT, Schnetkamp PP (2000) Molecular cloning and functional expression of the potassium-dependent sodium-calcium exchanger from human and chicken retinal cone photoreceptors. J Neurosci 20:1424-1434

144. Rätscho N, Scholten A, Koch KW (2009) Expression profiles of three novel sensory guanylate cyclases and guanylate cyclaseactivating proteins in the zebrafish retina. Biochim Biophys Acta 1793:1110-1114. https://doi.org/10.1016/j.bbamcr.2008.12.021

145. Raymond PA, Barthel LK (2004) A moving wave patterns the cone photoreceptor mosaic array in the zebrafish retina. Int $\mathrm{J}$ Dev Biol 48:935-945. https://doi.org/10.1387/ijdb.041873pr

146. Rebrik TI, Botchkina I, Arshavsky VY, Craft CM, Korenbrot JI (2012) CNG-modulin: a novel Ca-dependent modulator of ligand sensitivity in cone photoreceptor cGMP-gated ion channels. J
Neurosci 32:3142-3153. https://doi.org/10.1523/JNEUROSCI. 5518-11.2012

147. Reiländer H, Achilles A, Friedel U, Maul G, Lottspeich F, Cook $\mathrm{NJ}$ (1992) Primary structure and functional expression of the $\mathrm{Na} /$ $\mathrm{Ca}, \mathrm{K}$-exchanger from bovine rod photoreceptors. EMBO J 11: 1689-1695

148. Renninger SL, Gesemann M, Neuhauss SC (2011) Cone arrestin confers cone vision of high temporal resolution in zebrafish larvae. Eur J Neurosci 33:658-667. https://doi.org/10.1111/j.1460-9568. 2010.07574.x

149. Reuter TE, White RH, Wald G (1971) Rhodopsin and porphyropsin fields in the adult bullfrog retina. J Gen Physiol 58:351-371. https://doi.org/10.1085/jgp.58.4.351

150. Riazuddin SA, Shahzadi A, Zeitz C, Ahmed ZM, Ayyagari R, Chavali VR, Ponferrada VG, Audo I, Michiels C, Lancelot ME, Nasir IA, Zafar AU, Khan SN, Husnain T, Jiao X, MacDonald IM, Riazuddin S, Sieving PA, Katsanis N, Hejtmancik JF (2010) A mutation in SLC24A1 implicated in autosomal-recessive congenital stationary night blindness. Am J Hum Genet 87:523-531. https://doi.org/10.1016/j.ajhg.2010.08.013

151. Ribelayga C, Cao Y, Mangel SC (2008) The circadian clock in the retina controls rod-cone coupling. Neuron 59:790-801. https:// doi.org/10.1016/j.neuron.2008.07.017

152. Rinner O, Makhankov YV, Biehlmaier O, Neuhauss SC (2005) Knockdown of cone-specific kinase GRK7 in larval zebrafish leads to impaired cone response recovery and delayed dark adaptation. Neuron 47:231-242. https://doi.org/10.1016/j.neuron. 2005.06.010

153. Robinson J, Schmitt EA, Hárosi FI, Reece RJ, Dowling JE (1993) Zebrafish ultraviolet visual pigment: absorption spectrum, sequence, and localization. Proc Natl Acad Sci U S A 90:60096012. https://doi.org/10.1073/pnas.90.13.6009

154. Rosenbaum JL, Cole DG, Diener DR (1999) Intraflagellar transport: the eyes have it. J Cell Biol 144:385-388. https://doi.org/10. 1083/jcb.144.3.385

155. Sakisaka T, Itoh T, Miura K, Takenawa T (1997) Phosphatidylinositol 4,5-bisphosphate phosphatase regulates the rearrangement of actin filaments. Mol Cell Biol 17:3841-3849. https://doi.org/10.1128/mcb.17.7.3841

156. Sakurai K, Vinberg F, Wang T, Chen J, Kefalov VJ (2016) The $\mathrm{Na}(+) / \mathrm{Ca}(2+), \mathrm{K}(+)$ exchanger 2 modulates mammalian cone phototransduction. Sci Rep 6:32521. https://doi.org/10.1038/ srep32521

157. Samardzija M., Neuhauss S.C.F., Joly S. K-LM, C. G (2009) Animal models for retinal degeneration.

158. Sampath AP, Matthews HR, Cornwall MC, Fain GL (1998) Bleached pigment produces a maintained decrease in outer segment Ca2+ in salamander rods. J Gen Physiol 111:53-64

159. Saszik S, Bilotta J (1999) The effects of temperature on the darkadapted spectral sensitivity function of the adult zebrafish. Vision Res 39:1051-1058. https://doi.org/10.1016/s0042-6989(98) 00237-5

160. Sato M, Nakazawa M, Usui T, Tanimoto N, Abe H, Ohguro H (2005) Mutations in the gene coding for guanylate cyclaseactivating protein 2 (GUCA1B gene) in patients with autosomal dominant retinal dystrophies. Graefes Arch Clin Exp Ophthalmol 243:235-242. https://doi.org/10.1007/s00417-004-1015-7

161. Schlegel DK, Glasauer SMK, Mateos JM, Barmettler G, Ziegler U, Neuhauss SCF (2019) A new zebrafish model for CACNA2D4-dysfunction. Invest Ophthalmol Vis Sci 60:51245135. https://doi.org/10.1167/iovs.19-26759

162. Schmitz F (2014) Presynaptic [Ca(2+)] and GCAPs: aspects on the structure and function of photoreceptor ribbon synapses. Front Mol Neurosci 7:3. https://doi.org/10.3389/fnmol.2014.00003

163. Schmitz F, Königstorfer A, Südhof TC (2000) RIBEYE, a component of synaptic ribbons: a protein's journey through evolution 
provides insight into synaptic ribbon function. Neuron 28:857872. https://doi.org/10.1016/s0896-6273(00)00159-8

164. Scholten A, Koch KW (2011) Differential calcium signaling by cone specific guanylate cyclase-activating proteins from the zebrafish retina. PLoS One 6:e23117. https://doi.org/10.1371/ journal.pone. 0023117

165. Sears S, Erickson A, Hendrickson A (2000) The spatial and temporal expression of outer segment proteins during development of Macaca monkey cones. Invest Ophthalmol Vis Sci 41:971-979

166. Senin II, Fischer T, Komolov KE, Zinchenko DV, Philippov PP, Koch KW (2002) Ca2+-myristoyl switch in the neuronal calcium sensor recoverin requires different functions of $\mathrm{Ca} 2+$-binding sites. J Biol Chem 277:50365-50372. https://doi.org/10.1074/ jbc.M204338200

167. Sharma RK (2002) Evolution of the membrane guanylate cyclase transduction system. Mol Cell Biochem 230:3-30

168. Sieving PA, Richards JE, Naarendorp F, Bingham EL, Scott K, Alpern M (1995) Dark-light: model for nightblindness from the human rhodopsin Gly-90->Asp mutation. Proc Natl Acad Sci U S A 92:880-884. https://doi.org/10.1073/pnas.92.3.880

169. Sjostrand FS (1958) Ultrastructure of retinal rod synapses of the guinea pig eye as revealed by three-dimensional reconstructions from serial sections. J Ultrastruct Res 2:122-170. https://doi.org/ 10.1016/s0022-5320(58)90050-9

170. Sokolov M, Lyubarsky AL, Strissel KJ, Savchenko AB, Govardovskii VI, Pugh EN, Arshavsky VY (2002) Massive light-driven translocation of transducin between the two major compartments of rod cells: a novel mechanism of light adaptation. Neuron 34:95-106. https://doi.org/10.1016/s0896-6273(02) 00636-0

171. Spencer WJ, Lewis TR, Pearring JN, Arshavsky VY (2020) Photoreceptor discs: built like ectosomes. Trends Cell Biol 30: 904-915. https://doi.org/10.1016/j.tcb.2020.08.005

172. Stearns G, Evangelista M, Fadool JM, Brockerhoff SE (2007) A mutation in the cone-specific pde6 gene causes rapid cone photoreceptor degeneration in zebrafish. J Neurosci 27:13866-13874. https://doi.org/10.1523/JNEUROSCI.3136-07.2007

173. Steinberg RH, Fisher SK, Anderson DH (1980) Disc morphogenesis in vertebrate photoreceptors. J Comp Neurol 190:501-508. https://doi.org/10.1002/cne.901900307

174. Steindal IAF, Whitmore D (2020) Zebrafish circadian clock entrainment and the importance of broad spectral light sensitivity. Front Physiol 11:1002. https://doi.org/10.3389/fphys.2020.01002

175. Sterling P, Matthews G (2005) Structure and function of ribbon synapses. Trends Neurosci 28:20-29. https://doi.org/10.1016/j. tins.2004.11.009

176. Stiebel-Kalish H, Reich E, Rainy N, Vatine G, Nisgav Y, Tovar A, Gothilf Y, Bach M (2012) Gucy2f zebrafish knockdown-a model for Gucy2d-related leber congenital amaurosis. Eur J Hum Genet 20:884-889. https://doi.org/10.1038/ejhg.2012.10

177. Strissel KJ, Lishko PV, Trieu LH, Kennedy MJ, Hurley JB, Arshavsky VY (2005) Recoverin undergoes light-dependent intracellular translocation in rod photoreceptors. J Biol Chem 280: 29250-29255. https://doi.org/10.1074/jbc.M501789200

178. Strom TM, Nyakatura G, Apfelstedt-Sylla E, Hellebrand H, Lorenz B, Weber BH, Wutz K, Gutwillinger N, Rüther K, Drescher B, Sauer C, Zrenner E, Meitinger T, Rosenthal A, Meindl A (1998) An L-type calcium-channel gene mutated in incomplete $\mathrm{X}$-linked congenital stationary night blindness. Nat Genet 19:260-263. https://doi.org/10.1038/940

179. Sulmann S, Vocke F, Scholten A, Koch KW (2015) Retina specific GCAPs in zebrafish acquire functional selectivity in $\mathrm{Ca} 2+-$ sensing by myristoylation and $\mathrm{Mg} 2+$-binding. Sci Rep 5:11228. https://doi.org/10.1038/srep11228

180. Suzuki SC, Bleckert A, Williams PR, Takechi M, Kawamura S, Wong RO (2013) Cone photoreceptor types in zebrafish are generated by symmetric terminal divisions of dedicated precursors. Proc Natl Acad Sci U S A 110:15109-15114. https://oi. org/10.1073/pnas. 1303551110

181. Szymanska K, Johnson CA (2012) The transition zone: an essential functional compartment of cilia. Cilia 1:10. https://doi.org/10. 1186/2046-2530-1-10

182. Takechi M, Kawamura S (2005) Temporal and spatial changes in the expression pattern of multiple red and green subtype opsin genes during zebrafish development. J Exp Biol 208:1337-1345. https://doi.org/10.1242/jeb.01532

183. Tanaka T, Ames JB, Harvey TS, Stryer L, Ikura M (1995) Sequestration of the membrane-targeting myristoyl group of recoverin in the calcium-free state. Nature 376:444-447. https:// doi.org/10.1038/376444a0

184. Taylor JS, Van de Peer Y, Braasch I, Meyer A (2001) Comparative genomics provides evidence for an ancient genome duplication event in fish. Philos Trans R Soc Lond B Biol Sci 356:1661-1679. https://doi.org/10.1098/rstb.2001.0975

185. Terman JS, Remé CE, Terman M (1993) Rod outer segment disk shedding in rats with lesions of the suprachiasmatic nucleus. Brain Res 605:256-264. https://doi.org/10. 1016/0006-8993(93)91748-h

186. Thiadens AA, den Hollander AI, Roosing S, Nabuurs SB, Zekveld-Vroon RC, Collin RW, De Baere E, Koenekoop RK, van Schooneveld MJ, Strom TM, van Lith-Verhoeven JJ, Lotery AJ, van Moll-Ramirez N, Leroy BP, van den Born LI, Hoyng CB, Cremers FP, Klaver CC (2009) Homozygosity mapping reveals PDE6C mutations in patients with early-onset cone photoreceptor disorders. Am J Hum Genet 85:240-247. https:// doi.org/10.1016/j.ajhg.2009.06.016

187. tom Dieck S, Brandstätter JH (2006) Ribbon synapses of the retina. Cell Tissue Res 326:339-346. doi:https://doi.org/10.1007/ s00441-006-0234-0

188. Tsujikawa M, Malicki J (2004) Intraflagellar transport genes are essential for differentiation and survival of vertebrate sensory neurons. Neuron 42:703-716. https://doi.org/10.1016/s08966273(04)00268-5

189. Van Epps HA, Hayashi M, Lucast L, Stearns GW, Hurley JB, De Camilli P, Brockerhoff SE (2004) The zebrafish nrc mutant reveals a role for the polyphosphoinositide phosphatase synaptojanin 1 in cone photoreceptor ribbon anchoring. J Neurosci 24:8641-8650. https://doi.org/10.1523/JNEUROSCI. 2892-04.2004

190. Vandepoele K, De Vos W, Taylor JS, Meyer A, Van de Peer Y (2004) Major events in the genome evolution of vertebrates: paranome age and size differ considerably between ray-finned fishes and land vertebrates. Proc Natl Acad Sci U S A 101: 1638-1643. https://doi.org/10.1073/pnas.0307968100

191. Vinberg F, Chen J, Kefalov VJ (2018) Regulation of calcium homeostasis in the outer segments of rod and cone photoreceptors. Prog Retin Eye Res 67:87-101. https://doi.org/10.1016/j. preteyeres.2018.06.001

192. Vinberg F, Wang T, De Maria A, Zhao H, Bassnett S, Chen J, Kefalov VJ (2017) The $\mathrm{Na}^{+} / \mathrm{Ca}^{2+}, \mathrm{K}^{+}$exchanger NCKX4 is required for efficient cone-mediated vision. Elife 6. https://doi.org/ 10.7554/eLife.24550

193. Vinberg F, Wang T, Molday RS, Chen J, Kefalov VJ (2015) A new mouse model for stationary night blindness with mutant Slc24a1 explains the pathophysiology of the associated human disease. Hum Mol Genet 24:5915-5929. https://doi.org/10.1093/ hmg/ddv319

194. Vogalis F, Shiraki T, Kojima D, Wada Y, Nishiwaki Y, Jarvinen JL, Sugiyama J, Kawakami K, Masai I, Kawamura S, Fukada Y, Lamb TD (2011) Ectopic expression of cone-specific G-proteincoupled receptor kinase GRK7 in zebrafish rods leads to lower 
photosensitivity and altered responses. J Physiol 589:2321-2348. https://doi.org/10.1113/jphysiol.2010.204156

195. Volkov LI, Kim-Han JS, Saunders LM, Poria D, Hughes AEO, Kefalov VJ, Parichy DM, Corbo JC (2020) Thyroid hormone receptors mediate two distinct mechanisms of long-wavelength vision. Proc Natl Acad Sci U S A 117:15262-15269. https://doi. org/10.1073/pnas.1920086117

196. Wada Y, Sugiyama J, Okano T, Fukada Y (2006) GRK1 and GRK7: unique cellular distribution and widely different activities of opsin phosphorylation in the zebrafish rods and cones. $\mathrm{J}$ Neurochem 98:824-837. https://doi.org/10.1111/j.1471-4159. 2006.03920.x

197. Wald G (1939) The porphyropsin visual system. J Gen Physiol 22: 775-794. https://doi.org/10.1085/jgp.22.6.775

198. Wan L, Almers W, Chen W (2005) Two ribeye genes in teleosts: the role of Ribeye in ribbon formation and bipolar cell development. J Neurosci 25:941-949. https://doi.org/10.1523/ JNEUROSCI.4657-04.2005

199. Weiss ER, Ducceschi MH, Horner TJ, Li A, Craft CM, Osawa S (2001) Species-specific differences in expression of G-proteincoupled receptor kinase (GRK) 7 and GRK1 in mammalian cone photoreceptor cells: implications for cone cell phototransduction. J Neurosci 21:9175-9184

200. Weitz CJ, Miyake Y, Shinzato K, Montag E, Zrenner E, Went LN, Nathans J (1992) Human tritanopia associated with two amino acid substitutions in the blue-sensitive opsin. Am J Hum Genet 50:498-507

201. Weitz CJ, Went LN, Nathans J (1992) Human tritanopia associated with a third amino acid substitution in the blue-sensitive visual pigment. Am J Hum Genet 51:444-446

202. Weitz D, Ficek N, Kremmer E, Bauer PJ, Kaupp UB (2002) Subunit stoichiometry of the CNG channel of rod photoreceptors. Neuron 36:881-889. https://doi.org/10.1016/s0896-6273(02) 01098-x

203. Wilden U, Hall SW, Kühn H (1986) Phosphodiesterase activation by photoexcited rhodopsin is quenched when rhodopsin is phosphorylated and binds the intrinsic $48-\mathrm{kDa}$ protein of rod outer segments. Proc Natl Acad Sci U S A 83:1174-1178. https://doi. org/10.1073/pnas.83.5.1174

204. Williams DS (2002) Transport to the photoreceptor outer segment by myosin VIIa and kinesin II. Vision Res 42:455-462. https:// doi.org/10.1016/s0042-6989(01)00228-0

205. Willoughby JJ, Jensen AM (2012) Generation of a genetically encoded marker of rod photoreceptor outer segment growth and renewal. Biol Open 1:30-36. https://doi.org/10.1242/bio.2011016

206. Wong-Riley MT, Besharse JC (2012) The kinesin superfamily protein KIF17: one protein with many functions. Biomol Concepts 3:267-282. https://doi.org/10.1515/bmc-2011-0064

207. Woodruff ML, Sampath AP, Matthews HR, Krasnoperova NV, Lem J, Fain GL (2002) Measurement of cytoplasmic calcium concentration in the rods of wild-type and transducin knock-out mice. J Physiol 542:843-854

208. Wycisk KA, Budde B, Feil S, Skosyrski S, Buzzi F, Neidhardt J, Glaus E, Nürnberg P, Ruether K, Berger W (2006) Structural and functional abnormalities of retinal ribbon synapses due to Cacna2d4 mutation. Invest Ophthalmol Vis Sci 47:3523-3530. https://doi.org/10.1167/iovs.06-0271

209. Yamamoto S, Sippel KC, Berson EL, Dryja TP (1997) Defects in the rhodopsin kinase gene in the Oguchi form of stationary night blindness. Nat Genet 15:175-178. https://doi.org/10.1038/ ng0297-175

210. Yau KW, Baylor DA (1989) Cyclic GMP-activated conductance of retinal photoreceptor cells. Annu Rev Neurosci 12:289-327. https://doi.org/10.1146/annurev.ne.12.030189.001445

211. Yau KW, Nakatani K (1985) Light-suppressible, cyclic GMPsensitive conductance in the plasma membrane of a truncated rod outer segment. Nature 317:252-255. https://doi.org/10.1038/ $317252 \mathrm{a} 0$

212. Yoshimatsu T, Schröder C, Nevala NE, Berens P, Baden T (2020) Fovea-like photoreceptor specializations underlie single UV cone driven prey-capture behavior in zebrafish. Neuron 107:320 337.e326. https://doi.org/10.1016/j.neuron.2020.04.021

213. Young RW (1967) The renewal of photoreceptor cell outer segments. J Cell Biol 33:61-72. https://doi.org/10.1083/jcb.33.1.61

214. Young RW, Bok D (1969) Participation of the retinal pigment epithelium in the rod outer segment renewal process. J Cell Biol 42:392-403. https://doi.org/10.1083/jcb.42.2.392

215. Zang J, Keim J, Kastenhuber E, Gesemann M, Neuhauss SC (2015) Recoverin depletion accelerates cone photoresponse recovery. Open Biol 5. https://doi.org/10.1098/rsob.150086

216. Zang J, Matthews HR (2012) Origin and control of the dominant time constant of salamander cone photoreceptors. J Gen Physiol 140:219-233. https://doi.org/10.1085/jgp.201110762

217. Zang J, Neuhauss SCF (2018) The binding properties and physiological functions of recoverin. Front Mol Neurosci 11:473. https://doi.org/10.3389/fnmol.2018.00473

218. Zelinka CP, Sotolongo-Lopez M, Fadool JM (2018) Targeted disruption of the endogenous zebrafish rhodopsin locus as models of rapid rod photoreceptor degeneration. Mol Vis 24:587-602

219. Zhao X, Huang J, Khani SC, Palczewski K (1998) Molecular forms of human rhodopsin kinase (GRK1). J Biol Chem 273: 5124-5131. https://doi.org/10.1074/jbc.273.9.5124

220. Zheng J, Trudeau MC, Zagotta WN (2002) Rod cyclic nucleotidegated channels have a stoichiometry of three CNGA1 subunits and one CNGB1 subunit. Neuron 36:891-896. https://doi.org/10. 1016/s0896-6273(02)01099-1

221. Zhong H, Molday LL, Molday RS, Yau KW (2002) The heteromeric cyclic nucleotide-gated channel adopts a $3 \mathrm{~A}: 1 \mathrm{~B}$ stoichiometry. Nature 420:193-198. https://doi.org/10.1038/ nature 01201

222. Zimmermann MJY, Nevala NE, Yoshimatsu T, Osorio D, Nilsson DE, Berens P, Baden T (2018) Zebrafish differentially process color across visual space to match natural scenes. Curr Biol 28: 2018-2032.e2015. https://doi.org/10.1016/j.cub.2018.04.075

Publisher's note Springer Nature remains neutral with regard to jurisdictional claims in published maps and institutional affiliations. 